\title{
Comparative transcriptional study of the effects of high intracellular zinc on prostate carcinoma cells
}

\author{
POOI-FONG WONG ${ }^{1}$ and SAZALY ABUBAKAR ${ }^{2}$ \\ Departments of ${ }^{1}$ Pharmacology, Faculty of Medicine, and ${ }^{2}$ Medical Microbiology, \\ Faculty of Medicine, University of Malaya, 50603 Kuala Lumpur, Malaysia
}

Received September 2, 2009; Accepted November 4, 2009

DOI: $10.3892 /$ or_00000789

\begin{abstract}
The normally high concentration of zinc in normal prostate gland is significantly reduced in malignant prostate tissues, but its precise role in prostate tumorigenesis remains unclear. The present study investigates the growth and transcriptional responses of $\mathrm{LNCaP}$ prostate cancer cells to prolonged high $\mathrm{Zn}^{2+}$ treatment. Restoration of high intracellular $\mathrm{Zn}^{2+}$ to LNCaP cells significantly reduced the cell proliferation rate by $42.2 \pm 7.4 \%$ at the exponential growth phase and the efficiency of colony formation on soft agar by $87.2 \pm 2.5 \%$ at week 5 post-treatment. At least $161 \mathrm{LNCaP}$ cell genes responded to the high intracellular $\mathrm{Zn}^{2+}$, including $\sim 10.6 \%$ genes that negatively regulate cell growth and $\sim 16.1 \%$ genes that promote cancer cell proliferation. Inhibition of cell growth was transient as normal proliferation rate and colony formation efficiency were restored later even in the continuous presence of high intracellular $\mathrm{Zn}^{2+}$. RT-qPCR showed constitutively higher expression levels of $F B L$, CD164 and STEAP1 in LNCaP cells. FBL and CD164 were responsive to the treatment with $\mathrm{Zn}^{2+}$ in PNT2 prostate normal cells and were further overexpressed in the prolonged $\mathrm{Zn}^{2+}$ treated LNCaP cells. These observations suggest that in general high $\mathrm{Zn}^{2+}$ has suppressive effects on prostate cancer cell growth but continuous exposure to an environment of high $\mathrm{Zn}^{2+}$ can lead to the overexpression of cancer promoting genes such as FBL and CD164. This could be the antago-
\end{abstract}

Correspondence to: Dr Sazaly Abubakar, Department of Medical Microbiology, Faculty of Medicine, University of Malaya, 50603 Kuala Lumpur, Malaysia

E-mail: sazaly@ummc.edu.my; sazaly@um.edu.my

Abbreviations: CD164, CD164 sialomucin; E2F3, E2F transcription factor $3 ; F B L$, fibrillarin; RT-qPCR, quantitative real-time reverse transcriptase PCR; STEAP1, six-transmembrane epithelial antigen of the prostate 1; TPEN, $N, N, N^{\prime}, N^{\prime}$-tetrakis(2-pyridylmethyl)ethylenediamine

Key words: gene superinduction, microarray, trace element, tumorigenesis nistic mechanism used to overcome the initial cell growth inhibitory effects of high $\mathrm{Zn}^{2+}$. These findings support a potential detrimental role of $\mathrm{Zn}^{2+}$ in prostate cancer.

\section{Introduction}

Zinc is an essential trace element important for various biological processes. Imbalance in $\mathrm{Zn}^{2+}$ homeostasis is associated with immunological disorders such as inflammation, diabetes, asthma, rheumatoid arthritis and Alzheimer's disease $(1,2)$. It is also associated with pancreatic (3), prostatic (4) and esophageal squamous cell carcinoma (5). The diverse roles of this ion in regulating cell signal transduction pathways and gene expression perhaps plays a part in the development of these diseases. Microarray analyses on rat intestine (6) and liver tissues $(7,8)$, human leukocyte subsets and lymphoblastoid cell (9-13), human colon adenocarcinoma cells (14), esophageal squamous cell carcinoma (5) and normal prostate epithelial cells (15) identified group of genes affected by changes in $\mathrm{Zn}^{2+}$ status. These include genes that regulate cell growth, metabolism, DNA repair, signal transduction, protein folding, energy production and genes that encode for heavy metal binding proteins, transporters, cytokines, cytokine receptors, adhesion molecules and $\mathrm{T}$ cells functions. These findings strongly support the regulatory roles of $\mathrm{Zn}^{2+}$ in cell growth and proliferation.

In a number of studies, $\mathrm{Zn}^{2+}$ is also reported to play important roles in the development and progression of prostate cancer. Its uniquely high concentration in the prostate gland is essential for the normal function of prostate cells and spermatozoa (16). $\mathrm{Zn}^{2+}$ is found significantly lower in malignant prostate tissues in comparison to the normal tissues (17). $\mathrm{Zn}^{2+}$ regulates the signal transduction pathways that are implicated in prostate tumorigenesis $(18,19)$ and affects prostate cell growth and replication through various mechanisms (20-22). Whether $\mathrm{Zn}^{2+}$ regulates specific group of genes that are involved in prostate carcinogenesis or genes that increased malignant potentials in the cancerous prostate cells remained to be studied. In a recent study, we showed that high intracellular $\mathrm{Zn}^{2+}$ affected LNCaP prostatic cancer cell growth by modulating the ERK/VHR/ZAP70-associated pathways (23). The high intracellular $\mathrm{Zn}^{2+}$, however, has no influence on the prostate cancer cell senescence nor apoptosis (24). In the present study, we simulated the effects 


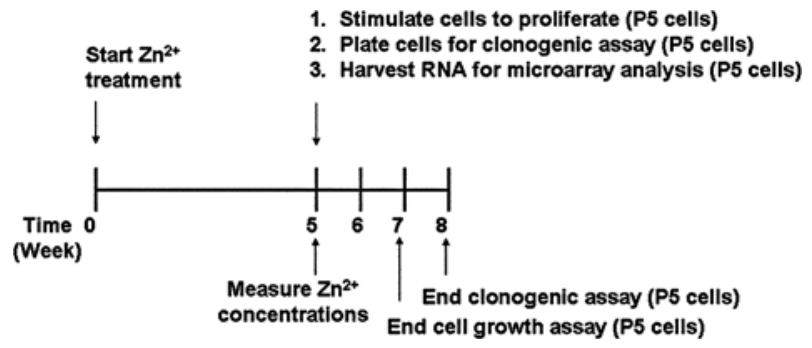

Figure 1. Schematic representation of timeline employed in the study. $\mathrm{LNCaP}$ prostate cancer cells were treated with $\mathrm{Zn}^{2+}$ for 5 weeks followed by subsequent analyses.

of progressive long-term intracellular $\mathrm{Zn}^{2+}$ accumulation by prolonged culturing of the LNCaP cells in growth medium supplemented with supraphysiologic concentration of $\mathrm{Zn}^{2+}$ and examined the effects on the prostate cancer cell growth and proliferation and on the $\mathrm{Zn}^{2+}$-responsive genes.

\section{Materials and methods}

Cell culture and treatments. Human prostate cancer cells, LNCaP.FGC, were purchased from American Type Culture Collection (Rockville, USA). Human normal prostate epithelial cells, PNT2 were obtained as gift from Dr R. Rosli, Universiti Putra Malaysia. The cells were cultured in RPMI1640 (Flowlab, Australia) supplemented with 10\% FBS (Biowhittaker, USA), nonessential amino acid (1 mM), L-glutamine $(2 \mathrm{mM})$ and $10 \mathrm{mM}$ HEPES at $37^{\circ} \mathrm{C}$ in humidified atmosphere of $5 \% \mathrm{CO}_{2}$. LNCaP cells were propagated in growth medium containing 1 or $10 \mu \mathrm{g} / \mathrm{ml}$ of $\mathrm{ZnSO}_{4}$ for 5 passages in 5 weeks and subsequently analyzed as shown in the schematic timeline (Fig. 1). Control cell cultures were supplemented with only the $\mathrm{Zn}^{2+}$ diluent and propagated in parallel with the $\mathrm{Zn}^{2+}$-supplemented cells. Cell proliferation rate and intracellular $\mathrm{Zn}^{2+}$ concentrations were measured as previously described (23). In separate experiments, shortterm $\mathrm{Zn}^{2+}$ treatment was performed by incubating $\mathrm{LNCaP}$ and PNT2 cells with growth medium supplemented with $10 \mu \mathrm{g} / \mathrm{ml} \mathrm{Zn}^{2+}$ for 2, 4, 8, 16, 24, 48 and $72 \mathrm{~h}$. Control untreated cells were incubated up to $72 \mathrm{~h}$. The influence of $\mathrm{Zn}^{2+}$ was also verified by treating cells with $100 \mu \mathrm{M} N, N$, $N^{\prime}, N^{\prime}$-tetrakis(2-pyridylmethyl)ethylenediamine (TPEN), a known chelator of $\mathrm{Zn}^{2+}$. At selected time points, total cellular RNA was harvested from the treated cells and stored until needed for quantitative real-time reverse transcriptase PCR (RT-qPCR).

Soft agar colony formation assay. LNCaP prostate cancer cells were treated with $\mathrm{Zn}^{2+}$ for 5 weeks. Cells were then assayed for anchorage-independent growth determined by their ability to form tumor colonies using soft agar colony formation assay. Single cell suspension was obtained by repeatedly passing cells through a $26 \mathrm{Gx}^{1}{ }^{1} 2^{\prime}$ needle (Terumo, Japan). Five thousand cells were then resuspended in growth medium containing $0.3 \%$ agar (DNA grade agarose, Promega, USA). The cell suspension was layered on top of a base layer consisting of $0.5 \%$ agar prepared in growth medium in $60-\mathrm{mm}$ plastic petri dishes (Falcon, USA). The cultures were incubated for 3 weeks at $37^{\circ} \mathrm{C}$ in a humidified chamber supplied with $5 \% \mathrm{CO}_{2}$ in air. The growth medium was replenished every 3 days and cell colonies were counted after 3 weeks of incubation. Only colonies $>0.5 \mathrm{~mm}$ were counted.

RNA extraction and target RNA preparation. Total cellular RNA of the $\mathrm{Zn}^{2+}$-treated cells at the end of passage 5 (week 5) from representative experiments $(n=3)$ was extracted from cells using TRI reagent ${ }^{\circledR}$ (Molecular Research Center, USA) and purified using RNeasy ${ }^{\circledR}$ Mini RNA Isolation Kit (Qiagen, Germany). Purified RNA integrity was checked by separating the RNA by electrophoresis in formaldehyde agarose gel. Complementary RNA (cRNA) amplification was then performed using Illumina ${ }^{\circledR}$ RNA Amplification Kit (Ambion, USA) according to the manufacturer's instructions. Approximately $100 \mathrm{ng}$ of total RNA was reverse transcribed using the T7 oligo (dT) primer to prime cDNA synthesis. Following the second strand cDNA synthesis and column purification, in vitro transcription (IVT) was performed using biotinylated UTP to synthesize biotinylated cRNA. The cRNAs were column purified and used for hybridization. Illumina Human Ref Seq-8 Sentrix Bead Chip Arrays consisting of $\sim 24,000$ transcript probes ( $\mathrm{n}=2$ for control and $\mathrm{n}=3$ for $\mathrm{Zn}^{2+}$-supplemented cells) were hybridized with $850 \mathrm{ng}$ biotinylated cRNA at $55^{\circ} \mathrm{C}$ for $16 \mathrm{~h}$. The arrays were washed, stained with strepavidin-Cy3 conjugate $(2 \mu \mathrm{g} /$ chip; GE Biosciences, USA) and scanned following the instruction for the Illumina BeadStation 500x (Illumina, USA).

Microarray data analysis. Microarray data were analyzed using the Genespring GX 7.3 (Agilent Technologies Inc., USA). Signal intensity values $<0.01$ were adjusted to the minimal intensity values of 0.01 . Data were normalized to 50th percentile per chip and then to the median value per gene to compensate for experimental biases introduced by individual chip and differences in the detection efficiency between different spots. The raw data intensity values were then $\log$ transformed $\left(\log _{2}\right)$ to increase detection efficiency in discriminating differences between groups whose withingroup variances are very different. Differential gene expression analysis was performed on Volcano plot using a cut-off fold change of 1.5 and parametric test with all available error estimates with Benjamini and Hochberg False Discovery Rate corrections (FDR of 0.05) (25). Hierarchical Clustering was performed on the normalized data using Genespring GX 7.3 (Agilent Technologies Inc.). Standard correlation was used as the dissimilarity estimates and average linkage method was used as the clustering algorithm. In the average linkage method, the distance between two clusters was calculated as the arithmetic mean of the distance between all possible pairs from the two clusters. Genes responsive to high intracellular $\mathrm{Zn}^{2+}$ were clustered based on biological process categories of the Gene Ontology Consortium (http:// www.geneontology.org) using a web-based annotation program called NMC Annotation Tool (26).

Quantitative real-time reverse transcriptase PCR ( $R T$ $q P C R)$. Total cellular RNA of cells treated with $\mathrm{Zn}^{2+}$ for 2,4 , 
Table I. Quantitative reverse transcriptase-polymerase chain reaction (RT-qPCR) amplification primer pairs used in the study.

\begin{tabular}{|c|c|c|c|}
\hline Gene & GenBank accesion no. & Sequence $\left(5^{\prime}-3^{\prime}\right)$ & Polarity \\
\hline $\begin{array}{l}\text { CD164 antigen, } \\
\text { sialomucin (CD164) }\end{array}$ & NM_006016 & $\begin{array}{l}\text { AACAGTTAGTGATTGTCAAGTGG } \\
\text { CAGGTTGTGAGGTTGGAGTC }\end{array}$ & $\begin{array}{l}\text { Sense } \\
\text { Anti-sense }\end{array}$ \\
\hline $\begin{array}{l}\text { Complement component } 1 \text {, } \\
\text { q subcomponent binding protein }(\mathrm{C} 1 \mathrm{QBP} 1)\end{array}$ & NM_001212 & $\begin{array}{l}\text { TGGCGAGTCTGAATGGAAGGATAC } \\
\text { АTCTGTCTGCTCTACTGGCTCTTG }\end{array}$ & $\begin{array}{l}\text { Sense } \\
\text { Anti-sense }\end{array}$ \\
\hline E2F transcription factor $3(\mathrm{E} 2 \mathrm{~F} 3)$ & NM_001949 & $\begin{array}{l}\text { TGTCCCATCGTGCTTCCATTCC } \\
\text { TCATCTGACCTGGTTCTCCTTTCC }\end{array}$ & $\begin{array}{l}\text { Sense } \\
\text { Anti-sense }\end{array}$ \\
\hline Fibrillarin (FBL) & NM_001436 & $\begin{array}{l}\text { GAGGCTTTAGAGGTCGTG } \\
\text { TCCACCATCACATTCTTCC }\end{array}$ & $\begin{array}{l}\text { Sense } \\
\text { Anti-sense }\end{array}$ \\
\hline Metallothioneins 1 and 2 (MT1 and 2) & $\begin{array}{l}\text { NM_005950 } \\
\text { X97260 }\end{array}$ & $\begin{array}{l}\text { GCACCTCCTGCAAGAAAAGCT } \\
\text { GCAGCCTTGGGCACACTT }\end{array}$ & $\begin{array}{l}\text { Sense } \\
\text { Anti-sense }\end{array}$ \\
\hline $\begin{array}{l}\text { Src homology } 2 \text { domain containing } \\
\text { transforming protein } 1 \text { (SHC1) }\end{array}$ & NM_003029 & $\begin{array}{l}\text { TTGGGATAACAGAGGCAGGAGTG } \\
\text { AAGGGAGGCAGGGCAGAGG }\end{array}$ & $\begin{array}{l}\text { Sense } \\
\text { Anti-sense }\end{array}$ \\
\hline $\begin{array}{l}\text { Six transmembrane epithelial antigen } \\
\text { of the prostate } 1 \text { (STEAP1) }\end{array}$ & NM_012449 & $\begin{array}{l}\text { GCGAAGAGTGGGTGGCTGAAG } \\
\text { GTGTGTGCTGAAGTTCTGAAGGG }\end{array}$ & $\begin{array}{l}\text { Sense } \\
\text { Anti-sense }\end{array}$ \\
\hline $\begin{array}{l}\text { Tumor-associated calcium } \\
\text { signal transducer } 1 \text { (TACSTD1) }\end{array}$ & NM_002354 & $\begin{array}{l}\text { GAATAATAATCGTCAATGCCAGTG } \\
\text { GCTCTCATCGCAGTCAGG }\end{array}$ & $\begin{array}{l}\text { Sense } \\
\text { Anti-sense }\end{array}$ \\
\hline $\begin{array}{l}\text { UDP glycosyltransferase } 2 \text { family, } \\
\text { polypeptide B7 (UGT2) }\end{array}$ & NM_001074 & $\begin{array}{l}\text { GCAGCAGAATACAGCCATTGGATG } \\
\text { TGAAGATGCCAGTACAGTCACCTC }\end{array}$ & $\begin{array}{l}\text { Sense } \\
\text { Anti-sense }\end{array}$ \\
\hline
\end{tabular}

8, 16, 24, 48, $72 \mathrm{~h}$ and those supplemented with $\mathrm{Zn}^{2+}$ for 5 weeks were isolated. RNAs were isolated using the TRI Reagent (Molecular Research Center) following the manufacturer's protocol. The RNA was treated with DNase and then $2 \mu \mathrm{g}$ of it was reverse-transcribed using SuperScript $^{\mathrm{TM}}$ II Reverse Transcriptase (Invitrogen, USA). RTqPCR was performed using the SYBR-Green dye (Qiagen, UK) method on DNA Engine Opticon II (Bio-Rad, USA) with oligonucleotide primers shown in Table I. The primers were designed using Beacon Designer ${ }^{\mathrm{TM}}$ software (Premier Biosoft International, USA). Melt curve analysis was performed after each amplification followed by gel electrophoresis and DNA sequencing. Standard curves for internal standard (18S rRNA) and target genes were generated by linear regression using threshold cycle values, $\mathrm{C}_{\mathrm{t}}$ versus $\log$ (standard dilutions). Amplification efficiency of the internal standard and target gene was determined in each run using the following equation: efficiency $=10^{(-1 / \text { slope })}-1$. The initial copy number of the target gene in each sample (control untreated and $\mathrm{Zn}^{2+}$-treated sample) was extrapolated from the standard curves. The initial target gene copy number was then normalized to the initial copy number of $18 \mathrm{~S}$ rRNA in the respective sample. Fold-change in gene expression was calculated by dividing the normalized copy number of the target gene in the $\mathrm{Zn}^{2+}$-treated sample with the normalized copy number of the target gene in the control untreated sample (27). RT-qPCR for all genes was performed in triplicates in at least three separate amplifications from 2 separate experiments. Data are presented as mRNA copies of target genes per $10^{8}$ copies of $18 \mathrm{~S}$ rRNA.
Statistical analysis. Statistical analyses were performed using GraphPad Prism Version 4.03 (GraphPad Software Inc., USA). Data were expressed as the mean \pm standard error of mean (SEM). Statistical differences were analyzed using t-test. A p-value $<0.05$ was considered as significantly different.

\section{Results}

The effects of a high intracellular $\mathrm{Zn}^{2+}$ level on LNCaP cells proliferation. High intracellular $\mathrm{Zn}^{2+}$ was restored to the LNCaP prostate cancer cells as previously described (23). The LNCaP prostate cancer cell proliferation rate after the long-term culture in $\mathrm{Zn}^{2+}$ was examined by stimulating the cells to proliferate at week six post-initiation of the $\mathrm{Zn}^{2+}$ treatment (Fig. 1). The proliferation rate of cells cultured in $1 \mu \mathrm{g} / \mathrm{ml} \mathrm{Zn^{2+ }}$ was comparable to that of the non $\mathrm{Zn}^{2+}$-treated cells (Fig. 2A). The proliferation rates for cells treated with supraphysiologic $\mathrm{Zn}^{2+}(10 \mu \mathrm{g} / \mathrm{ml})$, however, were significantly lowered at $42.2 \pm 7.4 \%, 76.7 \pm 2.0 \%$ and $35.8 \pm 5.6 \%$ in comparison to the non $\mathrm{Zn}^{2+}$-treated cells on days 3, 6 and 9, respectively (Fig. 2A). No significant growth differences were observed on day $12(\sim 7$ weeks post-initiation of the treatment) between the supraphysiologic $\mathrm{Zn}^{2+}$-supplemented cells $(13.2 \pm 1.7 \%)$ and cells supplemented with only physiologic $\mathrm{Zn}^{2+}$ or without additional $\mathrm{Zn}^{2+}$. In addition, the proliferation rate of cells supplemented with supraphysiologic $\mathrm{Zn}^{2+}$ was also significantly lower on days 3 and $6(48.1 \pm 6.6 \%$ and $44.9 \pm 4.8 \%$, respectively) when compared to that of the normal PNT2 prostate cells (Fig. 2A), suggesting that the 
A

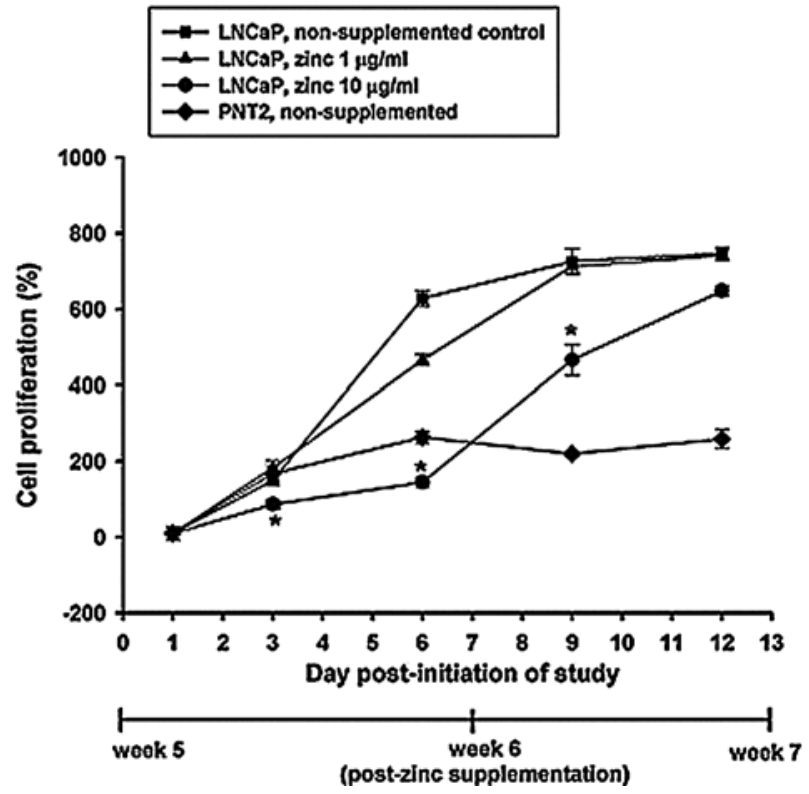

B

- LNCaP, non-supplemented control
- LNCaP, zinc $1 \mu \mathrm{g} / \mathrm{ml}$
- LNCaP, zinc $10 \mu \mathrm{g} / \mathrm{ml}$
- - LNCaP, non-supplemented control, TPEN-treated
- LNCaP, zinc $1 \mu \mathrm{g} / \mathrm{ml}$, TPEN-treated
- LNCaP, zinc $10 \mu \mathrm{g} / \mathrm{ml}$, TPEN-treated

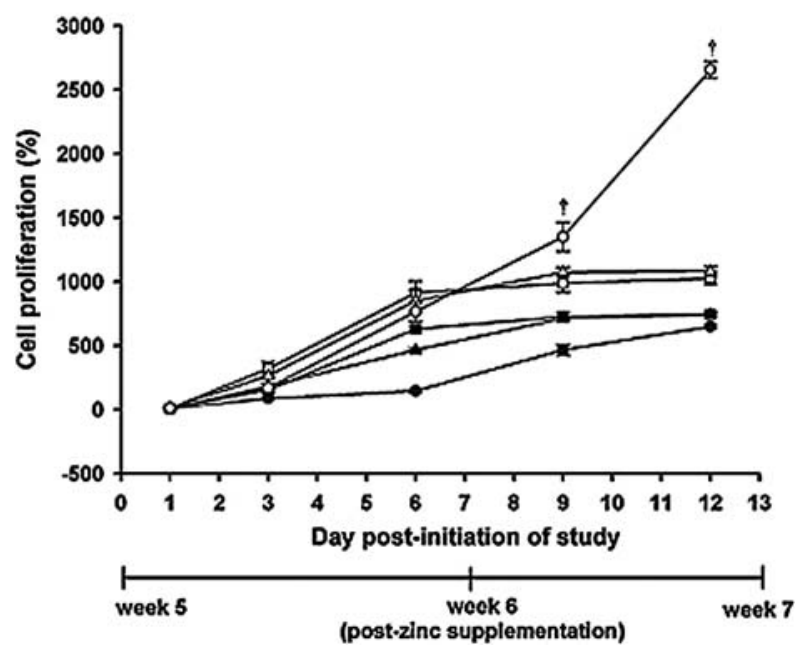

Figure 2. Effects of continuous supplementation with supraphysiologic $\mathrm{Zn}^{2+}$ concentration on LNCaP cell proliferation. Cell proliferation was determined over a period of 12 days and the percentage of viable cells was determined at selected intervals. The percentage of cell growth for cells cultured continuously in growth medium without additional $\mathrm{Zn}^{2+}$ (closed square), with only $1 \mu \mathrm{g} / \mathrm{ml} \mathrm{Zn}^{2+}$ (closed triangle) and with $10 \mu \mathrm{g} / \mathrm{ml} \mathrm{Zn}^{2+}$ (closed circle) were compared (A). The proliferation rates of cells when $\mathrm{Zn}^{2+}$ was chelated with TPEN from the control non-supplemented cells

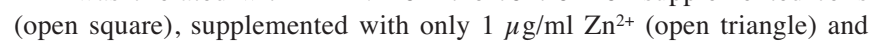

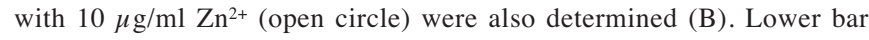
indicates week post-initiation of the $\mathrm{Zn}^{2+}$ treatment. Asterisk indicates significantly different ( $\mathrm{p}<0.05$, t-test) when compared to LNCaP cells cultured without additional $\mathrm{Zn}^{2+}$ and $\dagger$ indicates significantly different ( $\mathrm{p}<0.05$, t-test) when compared to LNCaP cells supplemented with 10 $\mu \mathrm{g} / \mathrm{ml} \mathrm{Zn}^{2+}$ and then treated with TPEN.

high intracellular $\mathrm{Zn}^{2+}$ inhibited LNCaP cells proliferation. In contrast, the proliferation rates on day 9 and 12 were increased by $111.8 \pm 18.4 \%$ and $149.6 \pm 5.0 \%$, respectively

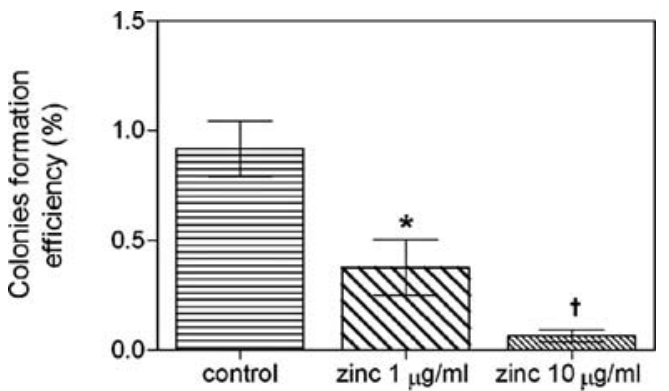

Figure 3. LNCaP cell anchorage-independent growth. LNCaP cells were cultured with and without $\mathrm{Zn}^{2+}$-supplementation. Colony formation efficiency was determined using soft agar assay at week 5 post-initiation of the $\mathrm{Zn}^{2+}$ treatment. Approximately 5,000 cells from single cell suspension were seeded onto each well. The number of colonies formed 3 weeks post-seeding was counted and the average colonies formation efficiency of six replicates from each sample \pm SEM is shown. ${ }^{*} \mathrm{p}=0.0491,{ }^{\dagger} \mathrm{p}<0.0001$ (t-test) indicate significantly different in comparison to control non-supplemented cells.

in comparison to the PNT2 cells. These suggested that the high intracellular $\mathrm{Zn}^{2+}$ markedly reduced the $\mathrm{LNCaP}$ cell proliferation rate during the exponential phase following stimulation of cell growth but the growth rate accelerated by day 9 post-initiation of the cell proliferation. When $\mathrm{Zn}^{2+}$ was chelated from the supraphysiologic $\mathrm{Zn}^{2+}$-supplemented LNCaP cells with TPEN, the cell proliferation rate increased dramatically by $427.2 \pm 55.1 \%, 189.6 \pm 24.5 \%$ and $309.9 \pm 10.3 \%$ on days 3,6 and 9, respectively (Fig. 2B) in comparison to their respective non TPEN-treated counterparts, suggesting that high intracellular $\mathrm{Zn}^{2+}$ inhibited cell growth and the inhibition was removed when $\mathrm{Zn}^{2+}$ was chelated.

The effects of a high intracellular $\mathrm{Zn}^{2+}$ level on LNCaP prostate cancer cell colony formation efficiency. The effects of $\mathrm{Zn}^{2+}$ on the LNCaP cell anchorage-independent growth after 5 weeks of treatment were determined using the soft agar colony formation assay. Data from representative experiments $(n=6)$ showed that the transformation frequency of the control non $\mathrm{Zn}^{2+}$-supplemented LNCaP cells was $0.92 \pm 0.12 \%$. The transformation frequencies for LNCaP cells supplemented with physiologic $(1 \mu \mathrm{g} / \mathrm{ml})$ and supraphysiologic $(10 \mu \mathrm{g} / \mathrm{ml}) \mathrm{Zn}^{2+}$ concentrations for 5 weeks were significantly reduced to $0.38 \pm 0.12 \%$ ( $\mathrm{p}<0.05$, t-test) and $0.06 \pm 0.02 \%$ ( $<<0.0001$, t-test), respectively (Fig. 3). These findings suggested that the restoration of high intracellular $\mathrm{Zn}^{2+}$ transiently restricted LNCaP prostate cancer cell anchorage-independent growth after 5 weeks of treatment (Fig. 3).

The effects of a high intracellular $\mathrm{Zn}^{2+}$ level on LNCaP prostate cancer cell gene expression. The gene expression profile of LNCaP prostate cancer cells treated with supraphysiologic $\mathrm{Zn}^{2+}(10 \mu \mathrm{g} / \mathrm{ml})$ for 5 weeks was examined using Illumina Human RefSeq-8 Sentrix Bead Chip 24,000 Gene Array (Illumina, USA). Data obtained were transformed and normalized to 50th percentile per chip and the median value per gene. Using a threshold factor of 1.5-fold change in signal intensity and Benjamini and Hochberg correction (FDR of 0.05), 161 zinc-upregulated genes were obtained without significantly downregulated genes (Fig. 4, Table II). 
Table II. LNCaP prostate cancer cell genes responsive to supraphysiologic $\mathrm{Zn}^{2+}$-treatment.

\begin{tabular}{|c|c|c|c|c|}
\hline No. & $\begin{array}{l}\text { GenBank } \\
\text { accession no. }\end{array}$ & Gene & $\begin{array}{l}\text { Fold- } \\
\text { change }\end{array}$ & $\begin{array}{l}\text { Corrected } \\
\text { p-value }\end{array}$ \\
\hline 1 & NM_001073 & $\begin{array}{l}\text { Homo sapiens UDP glycosyltransferase } 2 \text { family, } \\
\text { polypeptide B11 (UGT2B11), mRNA }\end{array}$ & 2.649 & 0.0295 \\
\hline 2 & NM_001074 & $\begin{array}{l}\text { Homo sapiens UDP glycosyltransferase } 2 \text { family, } \\
\text { polypeptide B7 (UGT2B7), mRNA }\end{array}$ & 2.496 & 0.0295 \\
\hline 3 & XM_378342 & Homo sapiens hypothetical gene supported by BC003510; NM_002823 & 2.07 & 0.0295 \\
\hline 4 & XM_352588 & Homo sapiens similar to $60 \mathrm{~S}$ ribosomal protein L21 (LOC377296), mRNA & 2 & 0.0295 \\
\hline 5 & NM_005950 & Homo sapiens metallothionein 1G (MT1G), mRNA & 1.986 & 0.0295 \\
\hline 6 & NM_006016 & Homo sapiens CD164 antigen, sialomucin (CD164), mRNA & 1.938 & 0.0295 \\
\hline 7 & XM_351136 & Homo sapiens similar to ribosomal protein L7 (LOC374811), mRNA & 1.929 & 0.0295 \\
\hline 8 & NM_012449 & $\begin{array}{l}\text { Homo sapiens six transmembrane epithelial antigen } \\
\text { of the prostate (STEAP), mRNA }\end{array}$ & 1.907 & 0.0295 \\
\hline 9 & XM_293276 & $\begin{array}{l}\text { Homo sapiens similar to Heat shock } 27 \mathrm{kDa} \text { protein (HSP } 27) \\
\text { (Stress-responsive protein } 27)(\mathrm{SRP} 27) \text { (Estrogen-regulated } 24 \mathrm{kDa} \text { protein) } \\
\text { (28 kDa heat shock protein) (LOC347348), mRNA }\end{array}$ & 1.906 & 0.0295 \\
\hline 10 & NM_001436 & Homo sapiens fibrillarin (FBL), mRNA & 1.905 & 0.0295 \\
\hline 11 & XM_210334 & $\begin{array}{l}\text { Homo sapiens similar to } 60 \mathrm{~S} \text { ribosomal protein L } 29 \\
\text { (Cell surface heparin binding protein HIP) (LOC284064), mRNA }\end{array}$ & 1.902 & 0.0295 \\
\hline 12 & NM_005949 & Homo sapiens metallothionein 1F (functional) (MT1F), mRNA & 1.898 & 0.0295 \\
\hline 13 & NM_002354 & $\begin{array}{l}\text { Homo sapiens tumor-associated calcium signal } \\
\text { transducer } 1 \text { (TACSTD1), mRNA }\end{array}$ & 1.896 & 0.0295 \\
\hline 14 & NM_138369 & $\begin{array}{l}\text { Homo sapiens family with sequence similarity } 44 \text {, } \\
\text { member B (FAM44B), mRNA }\end{array}$ & 1.892 & 0.0295 \\
\hline 15 & XM_377761 & Homo sapiens similar to ribosomal protein L22 (LOC402100), mRNA & 1.889 & 0.0295 \\
\hline 16 & XM_065828 & Homo sapiens similar to $60 \mathrm{~S}$ acidic ribosomal protein P1 (LOC130678), mRNA & 1.872 & 0.0295 \\
\hline 17 & NM_004859 & Homo sapiens clathrin, heavy polypeptide (Hc) (CLTC), mRNA & 1.86 & 0.0295 \\
\hline 18 & NM_006135 & $\begin{array}{l}\text { Homo sapiens capping protein (actin filament) muscle Z-line, } \\
\alpha 1 \text { (CAPZA1), mRNA }\end{array}$ & 1.841 & 0.0295 \\
\hline 19 & XM_291533 & $\begin{array}{l}\text { Homo sapiens similar to Transcription factor BTF3 } \\
\text { (RNA polymerase B transcription factor 3) (LOC343363), mRNA }\end{array}$ & 1.835 & 0.0295 \\
\hline 20 & NM_006743 & Homo sapiens RNA binding motif protein 3 (RBM3), mRNA & 1.822 & 0.0295 \\
\hline 21 & NM_020368 & Homo sapiens disrupter of silencing 10 (SAS10), mRNA & 1.818 & 0.0295 \\
\hline 22 & XM_041018 & Homo sapiens KIAA0367 protein (KIAA0367), mRNA & 1.805 & 0.0295 \\
\hline 23 & NM_145266 & $\begin{array}{l}\text { Homo sapiens nudix (nucleoside diphosphate linked moiety X) } \\
\text {-type motif } 8 \text { (NUDT8), mRNA }\end{array}$ & 1.804 & 0.0295 \\
\hline 24 & NM_005063 & Homo sapiens stearoyl-CoA desaturase $\delta$-9-desaturase) (SCD), mRNA & 1.799 & 0.0295 \\
\hline 25 & XM_060535 & $\begin{array}{l}\text { Homo sapiens similar to ribosomal protein L18a; } 60 \mathrm{~S} \text { ribosomal protein L18a } \\
\text { (LOC127545), mRNA }\end{array}$ & 1.785 & 0.0295 \\
\hline 26 & XM_292012 & $\begin{array}{l}\text { Homo sapiens similar to Polyadenylate-binding protein } 1 \\
\text { (Poly(A)-binding protein 1) (PABP 1) (LOC341315), mRNA }\end{array}$ & 1.78 & 0.0295 \\
\hline 27 & XM_372315 & Homo sapiens similar to 60S ribosomal protein L12 (LOC389974), mRNA & 1.766 & 0.0295 \\
\hline 28 & NM_001077 & $\begin{array}{l}\text { Homo sapiens UDP glycosyltransferase } 2 \text { family, } \\
\text { polypeptide B17 (UGT2B17), mRNA }\end{array}$ & 1.76 & 0.0295 \\
\hline 29 & NM_031263 & $\begin{array}{l}\text { Homo sapiens heterogeneous nuclear ribonucleoprotein } \mathrm{K} \\
\text { (HNRPK), transcript variant } 3 \text {, mRNA }\end{array}$ & 1.76 & 0.0295 \\
\hline 30 & NM_012248 & Homo sapiens selenophosphate synthetase 2 (SEPHS2), mRNA & 1.759 & 0.0295 \\
\hline 31 & NM_002439 & Homo sapiens mutS homolog 3 (E.coli) (MSH3), mRNA & 1.756 & 0.0323 \\
\hline 32 & XM_378321 & $\begin{array}{l}\text { Homo sapiens hypothetical gene supported } \\
\text { by AK096370 (LOC399972), mRNA }\end{array}$ & 1.754 & 0.0295 \\
\hline 33 & XM_352441 & Homo sapiens similar to Ubiquinol-cytochrome $\mathrm{C}$ reductase complex $11 \mathrm{kDa}$ & 1.751 & 0.031 \\
\hline
\end{tabular}
protein, mitochondrial precursor (Mitochondrial hinge protein) (Cytochrome $\mathrm{C} 1$, nonheme $11 \mathrm{kDa}$ protein) (Complex III subunit VIII) 
Table II. Continued.

\begin{tabular}{|c|c|c|c|c|}
\hline No. & $\begin{array}{c}\text { GenBank } \\
\text { accession no. }\end{array}$ & Gene & $\begin{array}{l}\text { Fold- } \\
\text { change }\end{array}$ & $\begin{array}{c}\text { Corrected } \\
\text { p-value }\end{array}$ \\
\hline 34 & NM_181843 & Homo sapiens oxysterol binding protein-like 8 (OSBPL8), mRNA & 1.751 & 0.0295 \\
\hline 35 & NM_004265 & Homo sapiens fatty acid desaturase 2 (FADS2), mRNA & 1.741 & 0.0295 \\
\hline 36 & XM_377480 & $\begin{array}{l}\text { Homo sapiens similar to 60S ribosomal protein L17 (L23) } \\
\text { (Amino acid starvation-induced protein) (ASI) (LOC401886), mRNA }\end{array}$ & 1.74 & 0.0295 \\
\hline 37 & NM_002822 & Homo sapiens PTK9 protein tyrosine kinase 9 (PTK9), transcript variant 1, mRNA & 1.738 & 0.0295 \\
\hline 38 & NM_001212 & $\begin{array}{l}\text { Homo sapiens complement component } 1 \text {, q subcomponent binding protein } \\
\text { (C1QBP), nuclear gene encoding mitochondrial protein, mRNA }\end{array}$ & 1.734 & 0.0295 \\
\hline 39 & NM_004060 & Homo sapiens cyclin G1 (CCNG1), transcript variant 1, mRNA & 1.73 & 0.0295 \\
\hline 40 & XM_292526 & $\begin{array}{l}\text { Homo sapiens similar to peptidylprolyl isomerase A (cyclophilin A) } \\
\text { (LOC342405), mRNA }\end{array}$ & 1.728 & 0.0295 \\
\hline 41 & NM_021218 & Homo sapiens chromosome 9 open reading frame 80 (C9orf80), mRNA & 1.726 & 0.0323 \\
\hline 42 & NM_175573 & $\begin{array}{l}\text { Homo sapiens adhesion regulating molecule } 1 \text { (ADRM1), } \\
\text { transcript variant } 2, \text { mRNA }\end{array}$ & 1.725 & 0.0298 \\
\hline 43 & NM_004685 & Homo sapiens myotubularin related protein 6 (MTMR6), mRNA & 1.721 & 0.0295 \\
\hline 44 & NM_003506 & Homo sapiens frizzled homolog 6 (Drosophila) (FZD6), mRNA & 1.717 & 0.0295 \\
\hline 45 & NM_000055 & Homo sapiens butyrylcholinesterase (BCHE), mRNA & 1.706 & 0.0295 \\
\hline 46 & NM_014016 & $\begin{array}{l}\text { Homo sapiens } \mathrm{SAC} 1 \text { suppressor of actin mutations 1-like } \\
\text { (yeast) (SACM1L), mRNA }\end{array}$ & 1.706 & 0.0295 \\
\hline 47 & NM_007363 & Homo sapiens non-POU domain containing, octamer-binding (NONO), mRNA & 1.687 & 0.0295 \\
\hline 48 & NM_004593 & $\begin{array}{l}\text { Homo sapiens splicing factor, arginine/serine-rich } 10 \\
\text { (transformer } 2 \text { homolog, Drosophila) (SFRS10), mRNA }\end{array}$ & 1.685 & 0.0295 \\
\hline 49 & NM_017932 & Homo sapiens hypothetical protein FLJ20700 (FLJ20700), mRNA & 1.683 & 0.0323 \\
\hline 50 & XM_377516 & $\begin{array}{l}\text { Homo sapiens similar to ribosomal protein L28; 60S ribosomal protein } \\
\text { L28 (LOC401900), mRNA }\end{array}$ & 1.676 & 0.0295 \\
\hline 51 & NM_006079 & $\begin{array}{l}\text { Homo sapiens } \mathrm{Cbp} / \mathrm{p} 300 \text {-interacting transactivator, } \\
\text { with Glu/Asp-rich carboxy-terminal domain, } 2 \text { (CITED2), mRNA }\end{array}$ & 1.675 & 0.0298 \\
\hline 52 & NM_022874 & $\begin{array}{l}\text { Homo sapiens survival of motor neuron } 1 \text {, telomeric } \\
(\mathrm{SMN} 1) \text {, transcript variant } \mathrm{b}, \mathrm{mRNA}\end{array}$ & 1.675 & 0.0295 \\
\hline 53 & NM_000441 & Homo sapiens solute carrier family 26 , member 4 (SLC26A4), mRNA & 1.674 & 0.0295 \\
\hline 54 & NR_003608 & Homo sapiens $\alpha$ tubulin-like (MGC16703), mRNA & 1.674 & 0.0298 \\
\hline 55 & NM_145266 & Homo sapiens NudC domain containing 2 (NUDCD2), mRNA & 1.67 & 0.0295 \\
\hline 56 & NM_173669 & Homo sapiens hypothetical protein FLJ34047 (FLJ34047), mRNA & 1.67 & 0.0295 \\
\hline 57 & NM_005782 & Homo sapiens THO complex 4 (THOC4), mRNA & 1.67 & 0.0295 \\
\hline 58 & NM_000687 & Homo sapiens $\mathrm{S}$-adenosylhomocysteine hydrolase (AHCY), mRNA & 1.669 & 0.0295 \\
\hline 59 & NM_030779 & $\begin{array}{l}\text { Homo sapiens potassium voltage-gated channel, subfamily } \mathrm{H} \\
\text { (eag-related), member } 6(\mathrm{KCNH} 6) \text {, transcript variant } 1 \text {, mRNA }\end{array}$ & 1.666 & 0.0295 \\
\hline 60 & XM_352086 & $\begin{array}{l}\text { Homo sapiens similar to Small nuclear ribonucleoprotein Sm D2 } \\
\text { (snRNP core protein D2) (Sm-D2) (LOC376142), mRNA }\end{array}$ & 1.663 & 0.0295 \\
\hline 61 & NM_014291 & $\begin{array}{l}\text { Homo sapiens glycine C-acetyltransferase (2-amino-3-ketobutyrate coenzyme } \\
\text { A ligase) (GCAT), nuclear gene encoding mitochondrial protein, mRNA }\end{array}$ & 1.663 & 0.0295 \\
\hline 62 & NM_201453 & Homo sapiens $\mathrm{COBW}$ domain containing 3 (CBWD3), mRNA & 1.659 & 0.0295 \\
\hline 63 & NM_003969 & $\begin{array}{l}\text { Homo sapiens ubiquitin-conjugating enzyme E2M } \\
\text { (UBC12 homolog, yeast) (UBE2M), mRNA }\end{array}$ & 1.658 & 0.0295 \\
\hline 64 & NM_017900 & Homo sapiens aurora-A kinase interacting protein (AKIP), mRNA & 1.657 & 0.0295 \\
\hline 65 & NM_001527 & Homo sapiens histone deacetylase 2 (HDAC2), mRNA & 1.657 & 0.0295 \\
\hline 66 & XM_352331 & $\begin{array}{l}\text { Homo sapiens similar to dJ612B18.1 (similar to } 40 \mathrm{~S} \\
\text { ribosomal protein) (LOC } 376679), \text { mRNA }\end{array}$ & 1.655 & 0.0295 \\
\hline 67 & NM_014501 & Homo sapiens ubiquitin-conjugating enzyme E2S (UBE2S), mRNA & 1.653 & 0.0295 \\
\hline 68 & NM_144682 & Homo sapiens hypothetical protein FLJ31952 (FLJ31952), mRNA & 1.653 & 0.0295 \\
\hline
\end{tabular}


Table II. Continued.

\begin{tabular}{|c|c|c|c|c|}
\hline No. & $\begin{array}{l}\text { GenBank } \\
\text { accession no. }\end{array}$ & Gene & $\begin{array}{l}\text { Fold- } \\
\text { change }\end{array}$ & $\begin{array}{l}\text { Corrected } \\
\text { p-value }\end{array}$ \\
\hline 69 & NM_080821 & Homo sapiens chromosome 20 open reading frame 108 (C20orf108), mRNA & 1.652 & 0.0295 \\
\hline 70 & NM_032026 & Homo sapiens TatD DNase domain containing 1 (TATDN1), mRNA & 1.652 & 0.0295 \\
\hline 71 & NM_022098 & $\begin{array}{l}\text { Homo sapiens X-prolyl aminopeptidase (aminopeptidase P) } 3 \text {, } \\
\text { putative (XPNPEP3), mRNA }\end{array}$ & 1.643 & 0.0295 \\
\hline 72 & NM_003952 & $\begin{array}{l}\text { Homo sapiens ribosomal protein } \mathrm{S} 6 \text { kinase, } 70 \mathrm{kDa} \text {, } \\
\text { polypeptide } 2 \text { (RPS6KB2), mRNA }\end{array}$ & 1.642 & 0.0295 \\
\hline 73 & XM_063202 & Homo sapiens similar to 60S ribosomal protein L23a (LOC122585), mRNA & 1.641 & 0.0298 \\
\hline 74 & NM_000982 & Homo sapiens ribosomal protein L21 (RPL21), mRNA & 1.639 & 0.0295 \\
\hline 75 & NM_203448 & Homo sapiens hypothetical protein MGC21881 (MGC21881), mRNA & 1.638 & 0.0295 \\
\hline 76 & NM_032194 & Homo sapiens brix domain containing 1 (BXDC1), mRNA & 1.635 & 0.0295 \\
\hline 77 & NM_000745 & $\begin{array}{l}\text { Homo sapiens cholinergic receptor, nicotinic, } \\
\text { a polypeptide } 5 \text { (CHRNA5), mRNA }\end{array}$ & 1.634 & 0.0295 \\
\hline 78 & NM_016097 & Homo sapiens immediate early response 3 interacting protein 1(IER3IP1), mRNA & 1.634 & 0.0295 \\
\hline 79 & NM_006948 & $\begin{array}{l}\text { Homo sapiens stress } 70 \text { protein chaperone, microsome-associated, } \\
60 \mathrm{kDa}(\mathrm{STCH}), \text { mRNA }\end{array}$ & 1.633 & 0.0306 \\
\hline 80 & NM_016126 & Homo sapiens chromosome 1 open reading frame 41 (C1orf41), mRNA & 1.632 & 0.0295 \\
\hline 81 & NM_032478 & $\begin{array}{l}\text { Homo sapiens mitochondrial ribosomal protein L38 (MRPL38), } \\
\text { nuclear gene encoding mitochondrial protein, mRNA }\end{array}$ & 1.628 & 0.0295 \\
\hline 82 & NM_016221 & Homo sapiens dynactin 4 (p62) (DCTN4), mRNA & 1.625 & 0.0298 \\
\hline 83 & NM_025065 & Homo sapiens brix domain containing 5 (BXDC5), mRNA & 1.62 & 0.0295 \\
\hline 84 & NM_005642 & $\begin{array}{l}\text { Homo sapiens TAF7 RNA polymerase II, TATA box binding protein } \\
\text { (TBP)-associated factor, } 55 \mathrm{kDa}(\mathrm{TAF} 7) \text {, mRNA }\end{array}$ & 1.62 & 0.0298 \\
\hline 85 & XM_350967 & Homo sapiens similar to $40 \mathrm{~S}$ ribosomal protein S8 (LOC374596), mRNA & 1.619 & 0.0397 \\
\hline 86 & NM_014820 & $\begin{array}{l}\text { Homo sapiens translocase of outer mitochondrial membrane } \\
70 \text { homolog A (yeast) (TOMM70A), mRNA }\end{array}$ & 1.617 & 0.0298 \\
\hline 87 & XM_380042 & Homo sapiens similar to $60 \mathrm{~S}$ ribosomal protein L15 (LOC402694), mRNA & 1.615 & 0.0447 \\
\hline 88 & NM_003143 & Homo sapiens single-stranded DNA binding protein 1 (SSBP1), mRNA & 1.613 & 0.0295 \\
\hline 89 & NM_004772 & Homo sapiens chromosome 5 open reading frame 13 (C5orf13), mRNA & 1.612 & 0.0295 \\
\hline 90 & NM_006756 & $\begin{array}{l}\text { Homo sapiens transcription elongation factor A (SII), } \\
1 \text { (TCEA } 1) \text {, transcript variant } 1, \text { mRNA }\end{array}$ & 1.61 & 0.0295 \\
\hline 91 & NM_177985 & $\begin{array}{l}\text { Homo sapiens ADP-ribosylation factor-like } 5 \text { (ARL5), } \\
\text { transcript variant } 2 \text {, mRNA }\end{array}$ & 1.606 & 0.0295 \\
\hline 92 & NM_173494 & Homo sapiens chromosome X open reading frame 41 (CXorf41), mRNA & 1.602 & 0.0295 \\
\hline 93 & NM_001064 & Homo sapiens transketolase (Wernicke-Korsakoff syndrome) (TKT), mRNA & 1.601 & 0.0295 \\
\hline 94 & NM_181054 & $\begin{array}{l}\text { Homo sapiens hypoxia-inducible factor } 1, \alpha \text { subunit } \\
\text { (basic helix-loop-helix transcription factor) (HIF1A), transcript variant } 2, \text { mRNA }\end{array}$ & 1.601 & 0.0298 \\
\hline 95 & NM_002154 & Homo sapiens heat shock $70 \mathrm{kDa}$ protein 4 (HSPA4), transcript variant 1 , mRNA & 1.596 & 0.0295 \\
\hline 96 & NM_003634 & Homo sapiens nipsnap homolog 1 (C.elegans) (NIPSNAP1), mRNA & 1.595 & 0.0295 \\
\hline 97 & NM_203373 & Homo sapienss F-box and leucine-rich repeat protein 22 (FBXL22), mRNA & 1.595 & 0.0295 \\
\hline 98 & NM_003666 & Homo sapiens basic leucine zipper nuclear factor 1 (JEM-1) (BLZF1), mRNA & 1.594 & 0.0298 \\
\hline 99 & NM_023009 & Homo sapiens MARCKS-like protein (MLP), mRNA & 1.594 & 0.0295 \\
\hline 100 & NM_032351 & $\begin{array}{l}\text { Homo sapiens mitochondrial ribosomal protein L45 (MRPL45), } \\
\text { nuclear gene encoding mitochondrial protein, mRNA }\end{array}$ & 1.593 & 0.0295 \\
\hline 101 & NM_152678 & $\begin{array}{l}\text { Homo sapiens family with sequence similarity } 116, \\
\text { member A (FAM116A), mRNA }\end{array}$ & 1.591 & 0.0298 \\
\hline 102 & NM_182763 & $\begin{array}{l}\text { Homo sapiens myeloid cell leukemia sequence } 1 \text { (BCL2-related) } \\
\text { (MCL1), transcript variant } 2, \text { mRNA }\end{array}$ & 1.586 & 0.0306 \\
\hline 103 & NM_003671 & Homo sapiens $\mathrm{CDC} 14$ cell division cycle 14 homolog B & 1.586 & 0.0298 \\
\hline
\end{tabular}


Table II. Continued.

\begin{tabular}{|c|c|c|c|c|}
\hline No. & $\begin{array}{l}\text { GenBank } \\
\text { accession no. }\end{array}$ & Gene & $\begin{array}{l}\text { Fold- } \\
\text { change }\end{array}$ & $\begin{array}{l}\text { Corrected } \\
\text { p-value }\end{array}$ \\
\hline 104 & NM_054026 & $\begin{array}{l}\text { Homo sapiens CCR4-NOT transcription complex, subunit } 7 \\
\text { (CNOT7), transcript variant } 2, \text { mRNA }\end{array}$ & 1.584 & 0.0295 \\
\hline 105 & NM_198264 & $\begin{array}{l}\text { Homo sapiens chromosome } 1 \text { open reading frame } 2 \text { (C1orf2), } \\
\text { transcript variant } 2, \text { mRNA }\end{array}$ & 1.582 & 0.0295 \\
\hline 106 & NM_031459 & Homo sapiens sestrin 2 (SESN2), mRNA & 1.582 & 0.031 \\
\hline 107 & NM_018467 & $\begin{array}{l}\text { Homo sapiens uncharacterized hematopoietic stem/ } \\
\text { progenitor cells protein MDS032 (MDS032), mRNA }\end{array}$ & 1.579 & 0.031 \\
\hline 108 & NM_017547 & $\begin{array}{l}\text { Homo sapiens FAD-dependent oxidoreductase } \\
\text { domain containing } 1 \text { (FOXRED1), mRNA }\end{array}$ & 1.577 & 0.0298 \\
\hline 109 & NM_033630 & $\begin{array}{l}\text { Homo sapiens SCAN domain containing } 1 \text { (SCAND1) } \\
\text { transcript variant } 2, \text { mRNA }\end{array}$ & 1.577 & 0.0295 \\
\hline 110 & NM_032710 & Homo sapiens hypothetical protein MGC13053 (MGC13053), mRNA & 1.576 & 0.0381 \\
\hline 111 & XM_370684 & $\begin{array}{l}\text { Homo sapiens similar to Elongation factor } 1-\alpha 1(\mathrm{EF}-1-\alpha-1) \\
\text { (Elongation factor } 1 \mathrm{~A}-1)(\mathrm{eEF} 1 \mathrm{~A}-1) \text { (Elongation factor } \mathrm{Tu}) \\
(\mathrm{EF}-\mathrm{Tu})(\mathrm{LOC} 387845), \mathrm{mRNA}\end{array}$ & 1.575 & 0.0295 \\
\hline 112 & XM_351078 & Homo sapiens similar to protein $40 \mathrm{kDa}$ (LOC374744), mRNA & 1.574 & 0.0295 \\
\hline 113 & NM_000994 & Homo sapiens ribosomal protein L32 (RPL32), mRNA & 1.573 & 0.0295 \\
\hline 114 & NM_025030 & Homo sapiens hypothetical protein FLJ20972 (FLJ20972), mRNA & 1.573 & 0.0295 \\
\hline 115 & NM_013410 & Homo sapiens adenylate kinase 3 (AK3), mRNA & 1.572 & 0.0295 \\
\hline 116 & XM_352732 & Homo sapiens similar to L21 ribosomal protein (LOC377653), mRNA & 1.572 & 0.0298 \\
\hline 117 & NM_016141 & $\begin{array}{l}\text { Homo sapiens dynein, cytoplasmic, light intermediate } \\
\text { polypeptide } 1 \text { (DNCLI1), mRNA }\end{array}$ & 1.57 & 0.0295 \\
\hline 118 & NM_014056 & Homo sapiens likely ortholog of mouse hypoxia induced gene 1 (HIG1), mRNA & 1.566 & 0.0295 \\
\hline 119 & XM_209959 & $\begin{array}{l}\text { Homo sapiens similar to chromosome } 7 \text { open reading frame } \\
17 \text { protein; } 16.7 \mathrm{kDa} \text { protein (LOC286224), mRNA }\end{array}$ & 1.565 & 0.0309 \\
\hline 120 & NM_015431 & Homo sapiens BIA2 (BIA2), mRNA & 1.563 & 0.0298 \\
\hline 121 & NM_031901 & $\begin{array}{l}\text { Homo sapiens mitochondrial ribosomal protein S21 (MRPS21), } \\
\text { nuclear gene encoding mitochondrial protein, transcript variant } 1, \text { mRNA }\end{array}$ & 1.562 & 0.0295 \\
\hline 122 & NM_006835 & Homo sapiens cyclin I (CCNI), mRNA & 1.561 & 0.0295 \\
\hline 123 & NM_001949 & Homo sapiens $\mathrm{E} 2 \mathrm{~F}$ transcription factor 3 (E2F3), mRNA & 1.56 & 0.0295 \\
\hline 124 & NM_003440 & Homo sapiens zinc finger protein 140 (ZNF140), mRNA & 1.559 & 0.0295 \\
\hline 125 & XM_371658 & $\begin{array}{l}\text { Homo sapiens similar to laminin receptor } 1 \text { (ribosomal protein SA); } \\
\text { P40-3, functional; P40-8, functional; laminin receptor } 1 \\
\text { ( } 67 \mathrm{kDa} \text {, ribosomal protein SA) (LOC389141), mRNA }\end{array}$ & 1.553 & 0.0295 \\
\hline 126 & NM_001660 & Homo sapiens ADP-ribosylation factor 4 (ARF4), mRNA & 1.552 & 0.0295 \\
\hline 127 & NM_133509 & $\begin{array}{l}\text { Homo sapiens RAD51-like } 1 \text { (S. cerevisiae) (RAD51L1), } \\
\text { transcript variant } 3 \text {, mRNA }\end{array}$ & 1.552 & 0.0298 \\
\hline 128 & NM_004768 & Homo sapiens splicing factor, arginine/serine-rich 11 (SFRS11), mRNA & 1.549 & 0.0295 \\
\hline 129 & NM_022483 & Homo sapiens hypothetical protein FLJ21657 (FLJ21657), mRNA & 1.547 & 0.0295 \\
\hline 130 & NM_002395 & Homo sapiens malic enzyme $1, \mathrm{NADP}(+)$-dependent, cytosolic (ME1), mRNA & 1.547 & 0.0295 \\
\hline 131 & NM_004986 & Homo sapiens kinectin 1 (kinesin receptor) (KTN1), mRNA & 1.545 & 0.0295 \\
\hline 132 & XM_352485 & $\begin{array}{l}\text { Homo sapiens similar to ATP synthase } \alpha \text { chain, } \\
\text { mitochondrial precursor (LOC376965), mRNA }\end{array}$ & 1.545 & 0.0295 \\
\hline 133 & NM_020387 & Homo sapiens RAB25, member RAS oncogene family (RAB25), mRNA & 1.537 & 0.0295 \\
\hline 134 & NM_024040 & Homo sapiens CUE domain containing 2 (CUEDC2), mRNA & 1.537 & 0.0295 \\
\hline 135 & NM_002156 & $\begin{array}{l}\text { Homo sapiens heat shock } 60 \mathrm{kDa} \text { protein } 1 \text { (chaperonin) (HSPD1), } \\
\text { nuclear gene encoding mitochondrial protein, transcript variant } 1, \text { mRNA }\end{array}$ & 1.532 & 0.0295 \\
\hline 136 & NM_178812 & Homo sapiens metadherin (MTDH), mRNA & 1.532 & 0.0295 \\
\hline 137 & NM_005367 & Homo sapiens melanoma antigen, family A, 12 (MAGEA12), mRNA & 1.531 & 0.0295 \\
\hline
\end{tabular}


Table II. Continued.

\begin{tabular}{|c|c|c|c|c|}
\hline No. & $\begin{array}{l}\text { GenBank } \\
\text { accession no. }\end{array}$ & Gene & $\begin{array}{l}\text { Fold- } \\
\text { change }\end{array}$ & $\begin{array}{l}\text { Corrected } \\
\text { p-value }\end{array}$ \\
\hline 138 & NM_001562 & $\begin{array}{l}\text { Homo sapiens interleukin } 18 \text { (interferon- } \gamma \text {-inducing factor) } \\
\text { (IL18), mRNA }\end{array}$ & 1.53 & 0.04 \\
\hline 139 & NM_003352 & $\begin{array}{l}\text { Homo sapiens SMT3 suppressor of mif two } 3 \text { homolog } 1 \text { (yeast) } \\
\text { (SUMO1), mRNA }\end{array}$ & 1.529 & 0.0341 \\
\hline 140 & NM_016308 & $\begin{array}{l}\text { Homo sapiens cytidine monophosphate (UMP-CMP) kinase } 1 \text {, } \\
\text { cytosolic (CMPK1), mRNA }\end{array}$ & 1.526 & 0.0295 \\
\hline 141 & XM_352661 & $\begin{array}{l}\text { Homo sapiens similar to dynein, cytoplasmic, } \\
\text { light peptide (LOC } 377527) \text {, mRNA }\end{array}$ & 1.526 & 0.0295 \\
\hline 142 & NM_001029 & Homo sapiens ribosomal protein S26 (RPS26), mRNA & 1.526 & 0.0295 \\
\hline 143 & NM_003746 & Homo sapiens dynein, cytoplasmic, light polypeptide 1 (DNCL1), mRNA & 1.524 & 0.0295 \\
\hline 144 & NM_006457 & Homo sapiens PDZ and LIM domain 5 (PDLIM5), mRNA & 1.523 & 0.0306 \\
\hline 145 & NM_005274 & $\begin{array}{l}\text { Homo sapiens guanine nucleotide binding protein } \\
\text { G protein), }-\gamma 5 \text { (GNG5), mRNA }\end{array}$ & 1.523 & 0.0295 \\
\hline 146 & NM_183003 & $\begin{array}{l}\text { Homo sapiens cytochrome c oxidase subunit VIIa } \\
\text { polypeptide } 3 \text { (liver) (COX7A3), mRNA }\end{array}$ & 1.522 & 0.0485 \\
\hline 147 & NM_014045 & $\begin{array}{l}\text { Homo sapiens low density lipoprotein receptor-related } \\
\text { protein } 10 \text { (LRP10), mRNA }\end{array}$ & 1.522 & 0.0295 \\
\hline 148 & NM_007265 & Homo sapiens ecdysoneless homolog (Drosophila) (ECD), mRNA & 1.52 & 0.0298 \\
\hline 149 & NM_198853 & Homo sapiens tripartite motif-containing 50C (TRIM50C), mRNA & 1.514 & 0.0295 \\
\hline 150 & NM_000791 & Homo sapiens dihydrofolate reductase (DHFR), mRNA & 1.513 & 0.0373 \\
\hline 151 & NM_020841 & $\begin{array}{l}\text { Homo sapiens } \mathrm{p} 53 \text { target zinc finger protein (WIG1), } \\
\text { transcript variant } 2, \text { mRNA }\end{array}$ & 1.513 & 0.0298 \\
\hline 152 & NM_032796 & $\begin{array}{l}\text { Homo sapiens synapse associated protein } 1 \text {, } \\
\text { SAP47 homolog (Drosophila) (SYAP1), mRNA }\end{array}$ & 1.513 & 0.0298 \\
\hline 153 & NM_006763 & Homo sapiens BTG family, member 2 (BTG2), mRNA & 1.511 & 0.0295 \\
\hline 154 & XM_293026 & $\begin{array}{l}\text { Homo sapiens similar to UNR-interacting protein } \\
\text { (WD-40 repeat protein PT-WD) (MAP activator with WD repeats) } \\
\text { (LOC344382), mRNA }\end{array}$ & 1.508 & 0.0463 \\
\hline 155 & NM_017636 & $\begin{array}{l}\text { Homo sapiens transient receptor potential cation channel, } \\
\text { subfamily M, member } 4 \text { (TRPM4), mRNA }\end{array}$ & 1.508 & 0.0463 \\
\hline 156 & NM_014637 & $\begin{array}{l}\text { Homo sapiens mitochondrial fission regulator } 1 \text { (MTFR1), } \\
\text { nuclear gene encoding mitochondrial protein, mRNA }\end{array}$ & 1.505 & 0.0295 \\
\hline 157 & NM_013402 & Homo sapiens fatty acid desaturase 1 (FADS1), mRNA & 1.502 & 0.0381 \\
\hline 158 & NM_015251 & Homo sapiens KIAA0431 protein (KIAA0431), mRNA & 1.501 & 0.0401 \\
\hline 159 & NM_183352 & $\begin{array}{l}\text { Homo sapiens SEC13 homolog (S. cerevisiae) (SEC13), } \\
\text { transcript variant } 1, \text { mRNA }\end{array}$ & 1.501 & 0.0357 \\
\hline 160 & NM_003029 & $\begin{array}{l}\text { Homo sapiens } \mathrm{SHC} \text { (Src homology } 2 \text { domain containing) } \\
\text { transforming protein } 1 \text { (SHC1), mRNA }\end{array}$ & 1.501 & 0.0295 \\
\hline 161 & NM_016535 & Homo sapiens zinc finger protein 581 (ZNF581), mRNA & 1.501 & 0.0295 \\
\hline
\end{tabular}

The mRNA expressions of selected genes from the list of genes that were highly responsive to the $\mathrm{Zn}^{2+}$ treatment were further quantified using quantitative real-time RT-PCR (RTqPCR). Of the 9 selected genes, 4 genes showed comparable mRNA expression fold changes to those found in microarray analysis while the other 5 genes had even higher fold changes when compared to those identified from the microarray analysis (Fig. 5). At least 12 different functional gene groups were obtained from the 161 genes found responsive to high intracellular $\mathrm{Zn}^{2+}$ when clustered based on biological process categories of the Gene Ontology Consortium (Fig. 6) using the web-based annotation program NMC Annotation Tool (26). These groups consist of genes that encode for proteins involved in translation $(10.6 \%)$, cell proliferation/cell death/ cell cycle regulation $(7.6 \%)$, signal transduction $(8.1 \%)$, metabolism $(8.6 \%)$, transcription $(8.6 \%)$, ion/protein transport 


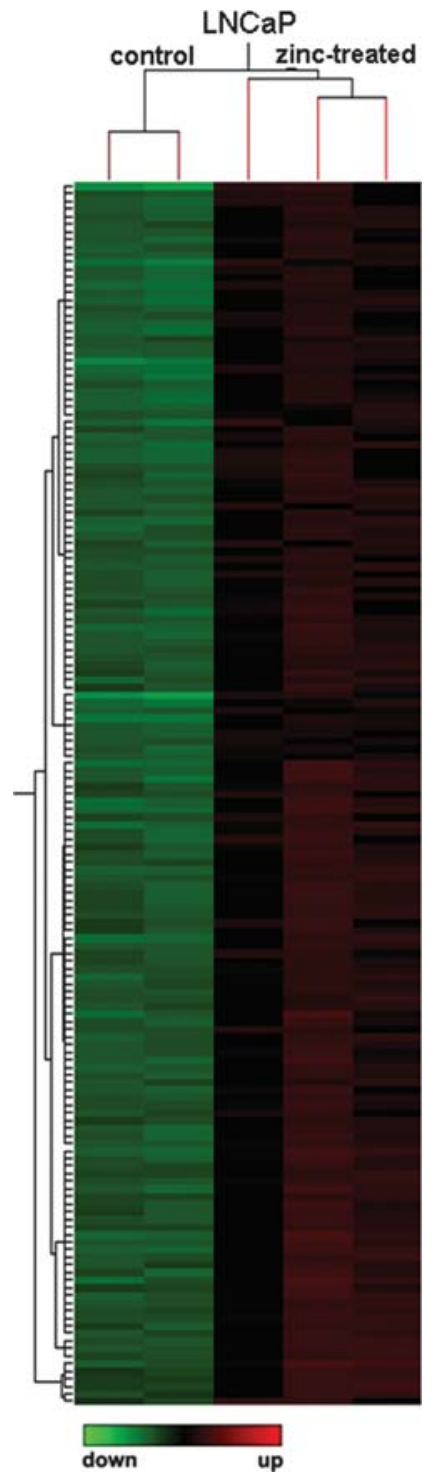

Figure 4. Hierarchical clustering of genes based on responsiveness to $\mathrm{Zn}^{2+}$. LNCaP cells cultured in growth medium without $\mathrm{Zn}^{2+}$ supplementation or

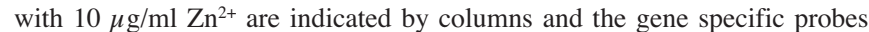
are indicated by rows. A total of 161 significant $(\mathrm{p}<0.05$, $\mathrm{t}$-test) gene specific probe signals were analyzed. Total cellular RNA of the $\mathrm{Zn}^{2+}$-treated cells at the end of passage 5 (week 5) was used for preparation of target RNA for hybridization.

(7.6\%), RNA processing $(6.1 \%)$, protein folding/modification $(5.1 \%)$, cell adhesion/cell motility (4.0\%), DNA repair/DNA replication $(4.5 \%)$ and multicellular organismal development $(4.0 \%)$. Several genes that are involved in various biological processes such as immune responses, secretion, excretion, endocytosis and sensory perception of sound were grouped under 'other' category $(7.1 \%)$ and a larger fraction of the genes $(18.2 \%)$, comprised of hypothetical genes or genes with unknown function were grouped under 'uncharacterized' category.

The microarray analysis revealed several genes associated with cell growth inhibition, DNA damage/repair, oxidative stress and decreased tumor colony formation abilities were affected by the high intracellular $\mathrm{Zn}^{2+}$ treatment of the LNCaP cells. These included BTG2 (28), CCNG1 (29), KIAA0367/BMCCl (30), ClQBP/HABPl/gClqR (31), HSPDI

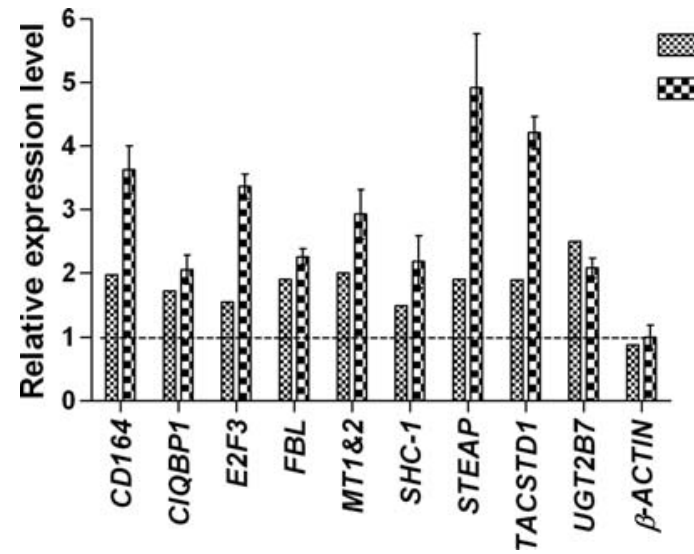

Figure 5. Gene expression in LNCaP prostate cancer cells in response to prolonged treatment with supraphysiologic $\mathrm{Zn}^{2+}$. The mRNA expression ( $>1.5$-fold increase) changes identified by microarray analysis were evaluated using quantitative RT-PCR (RT-qPCR). The mRNA copies were normalized to $18 \mathrm{~S}$ rRNA and then plotted as ratio of the corresponding levels in the $\mathrm{Zn}^{2+}$-treated cells in comparison to the non $\mathrm{Zn}^{2+}$-supplemented cells (mean \pm SEM). The average of fold increase of all the selected genes was 1-fold over that of the non $\mathrm{Zn}^{2+}$ treated LNCaP cells. The values were obtained from at least three independent amplifications of triplicates.

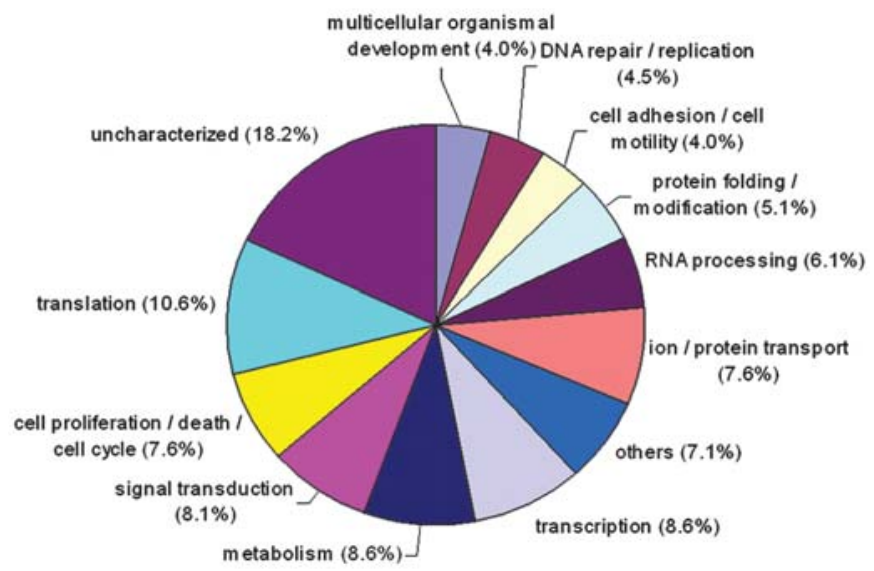

Figure 6. Functional grouping of genes that were upregulated in LNCaP cells following restoration of high intracellular $\mathrm{Zn}^{2+}$.

(32), SESN2 (33), MLP (34), RBM3 (35), MT-1F (36) and $S H C$-1 (37) that negatively regulate cell growth. Whereas, RAD51L1, MSH3 (38), ATMIN (39) and NONO (40) were upregulated usually in response to DNA damage/repair and ME1 (41), was upregulated in response to oxidative stress. MT-IF (42) and WIG1/ZMAT3 (43) found upregulated were usually associated to a decrease in tumor colony formation efficiency similar to results obtained when the LNCaP cells were treated with supraphysiologic $\mathrm{Zn}^{2+}$ at 5 weeks posttreatment (Table III). Approximately $16.1 \%$ of the upregulated genes, however, were genes commonly found overexpressed in malignant tissues/cells and those that promote cell proliferation, adhesion and migration (Table III). These included CD164 (44), FASN (45), FAD (46), NONO/Nmt55 (47), CCNG1 (48), TACSTDI (49), ADRMI (50), HIFIA (51), MAGE A12 (52), RPL4, RPL23a (53), CITED2 (54), $A R L 5$ (55) and FBL (56). Some of these genes were also 
Table III. Selected $\mathrm{LNCaP}$ cell genes that responded to the high intracellular $\mathrm{Zn}^{2+}$ treatment.

\begin{tabular}{ll}
\hline Gene symbol & \\
\hline$A H C Y, B T G 2, C C N G 1, C 1 Q B P 1, H S P D 1, M L P$, & Cellular effects \\
$K I A A 0367 / B M C C 1, M T-1 F, R B M 3, S E S N 2, S H C-1$ & Cell growth inhibition, apoptosis \\
$A T M I N, M S H 3, M T-1 F, N O N O, S E S N 2, R A D 51 L 1, M E 1$ & \\
$M T-1 F, W I G 1 / Z M A T 3$ & DNA damage/repair, oxidative stress, hypoxia \\
$S C D, C D 164^{\text {a }}, C I T E D 2, E 2 F 3^{\text {a }}, S T E A P 1^{\text {a }}, A D R M 1$ & Decrease tumour colonies formation capability \\
$A H R, E 2 F 3, J E M-1 / B L Z F 1, S C D, S H C-1, T K T$ & Metastasis and invasion \\
$A D R M 1, C C N G 1, F A D 2, F B L, N O N O$, & Cell proliferation \\
$R P L 4, R P L 23 a, T A C S T D 1^{\text {a }}$ & Overexpressed in cancers: prostate cancer \\
$E 2 F 3$ and $S T E A P 1$ & \\
$A R L 5, K T N 1$ and $M T-1 F$ & Prostate, bladder, colon, ovarian cancer, Ewing sarcoma \\
$R P L 29$ & Liver cancer \\
$A H C Y$ & Colon cancer \\
$H I F 1 A$ & Ovarian cancer \\
$M A G E A 12$ & Rectal cancer \\
$H I G 1, F B L^{\text {a }}$ & Oral squamous carcinoma \\
\hline
\end{tabular}

${ }^{\mathrm{a}}$ Genes selected for short-term $\mathrm{Zn}^{2+}$-treatment and RT-qPCR analysis in LNCaP and PNT2 cells.

Table IV. Comparison of mRNA expression levels between LNCaP prostate cancer and PNT2 normal cell genes at $72 \mathrm{~h}$ post $\mathrm{Zn}^{2+}$-treatment.

\begin{tabular}{lccccc}
\hline \multirow{2}{*}{ Genes } & \multicolumn{2}{c}{ LNCaP $^{\mathrm{a}}$} & & \multicolumn{2}{c}{$\mathrm{PNT2}^{\mathrm{a}}$} \\
\cline { 2 - 3 } \cline { 5 - 6 } & $\begin{array}{c}\text { Control } \\
\text { (Untreated) }\end{array}$ & $\mathrm{Zn}^{2+}$-treated & $(10 \mu \mathrm{g} / \mathrm{ml})$ & $\begin{array}{c}\text { Control } \\
\text { (Untreated })\end{array}$ & $\begin{array}{c}\mathrm{Zn}^{2+} \text {-treated } \\
(10 \mu \mathrm{g} / \mathrm{ml})\end{array}$ \\
\hline CD164 & ++ & +++ & ++ & +++ \\
FBL & +++ & ++++ & + & ++ \\
TACSTD1 & +++ & ++++ & +++ & ++++ \\
E2F3 & +++ & ++++ & +++ & +++ \\
STEAP1 & +++ & +++ & & + & + \\
\hline
\end{tabular}

${ }^{\mathrm{a}} \mathrm{mRNA}$ copies per $10^{8}$ copies of $18 \mathrm{~S}$ rRNA;,$+<5.0 \times 10^{7}$ copies; ,$++ 5.0 \times 10^{7}-1.0 \times 10^{8}$ copies;,$+++ 1.0 \times 10^{8}-5.0 \times 10^{8}$ copies; ++++ , $>5.0 \times 10^{8}$ copies.

previously reported to be overexpressed in prostate cancer tissues $(44-47,49,50,53,57-59)$.

The effects of short-term $\mathrm{Zn}^{2+}$ treatments on LNCaP and PNT2 cell gene expression. Five genes identified as highly responsive ( $>1.7$-fold, with exception of E2F3 gene at $\sim 1.5$ fold) to supraphysiologic $\mathrm{Zn}^{2+}$ concentration from the $161 \mathrm{Zn}^{2+}$-responsive genes were selected for further examination in LNCaP prostate cancer cells and PNT2 prostate normal cells. PNT2 and LNCaP cells were treated with $10 \mu \mathrm{g} / \mathrm{ml} \mathrm{Zn}^{2+}$ and the mRNA expression levels at intervals up to $72 \mathrm{~h}$ were quantified by quantitative reverse transcriptase PCR (RT-qPCR). Results obtained for LNCaP cells treated with $\mathrm{Zn}^{2+}(10 \mu \mathrm{g} / \mathrm{ml})$ for 5 weeks were included for comparison. Comparative transcription studies of CD164, E2F3, FBL, STEAPI and TACSTDI genes showed a timedependent increase in mRNA expression levels of these genes in the $\mathrm{Zn}^{2+}$-treated LNCaP cells beginning at $16 \mathrm{~h}$ post-treatment (Fig. 7). The mRNA expression levels of these genes in the non $\mathrm{Zn}^{2+}$-treated cells harvested at $72 \mathrm{~h}$ and cells treated with $100 \mu \mathrm{M} \mathrm{N}, N, N^{\prime}, N^{\prime}$-tetrakis(2-pyridylmethyl)ethylenediamine (TPEN) to chelate $\mathrm{Zn}^{2+}$ remained lower than the $\mathrm{Zn}^{2+}$-treated cells. At $16 \mathrm{~h}$ post-treatment, the mRNA levels of CD164, FBL and TACSTD1 genes of the $\mathrm{Zn}^{2+}$-treated LNCaP cells were 2.2 \pm 0.3 -fold, $4.5 \pm 0.7$-fold and 2.7 \pm 0.6 -fold, respectively, higher than the non $\mathrm{Zn}^{2+}$ treated LNCaP cells (Fig. 7A, C and E; p <0.01, t-test). The mid logarithmic increase in the mRNA expression for CD164, FBL and TACSTD1 genes were observed at $\sim 18 \mathrm{~h}$ post-treatment (Fig. 7). At $72 \mathrm{~h}$ post-treatment, the mRNA expression of CD164, FBL and TACSTD1 had increased by 3.5 \pm 0.4 -fold ( $\mathrm{p}<0.01, \mathrm{t}$-test), 5.6 \pm 0.6 -fold $(\mathrm{p}<0.001, \mathrm{t}$-test) and 5.1 \pm 0.5 -fold $(\mathrm{p}<0.001, \mathrm{t}$-test $)$ when compared to the non $\mathrm{Zn}^{2+}$-treated LNCaP cells (Table IV). On the other hand, the mid logarithmic increase in the mRNA expression of E2F3 and STEAPl genes was at $\sim 36 \mathrm{~h}$ post-treatment suggesting a delay in response to $\mathrm{Zn}^{2+}$ by these genes. At $48 \mathrm{~h}$ posttreatment, the mRNA expression levels of E2F3 and STEAP1 of the $\mathrm{Zn}^{2+}$-treated $\mathrm{LNCaP}$ cells were $3.03 \pm 0.7$-fold ( $\mathrm{p}=0.046$, $\mathrm{t}$-test) and 2.0 \pm 0.3 -fold ( $<<0.001$, t-test), respectively, higher than the non $\mathrm{Zn}^{2+}$-treated LNCaP cells and remained almost unchanged at $72 \mathrm{~h}$ post-treatment $(3.3 \pm 0.3$-fold and 3.1 \pm 0.3 fold, respectively) (Fig. 7B and D; Table IV). At 5 weeks post-treatment, the mRNA expression of $C D 164, F B L$, TACSTD 1, E2F3 and STEAP1 genes remained high, at

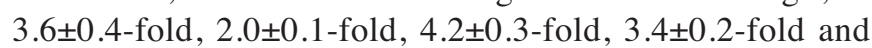



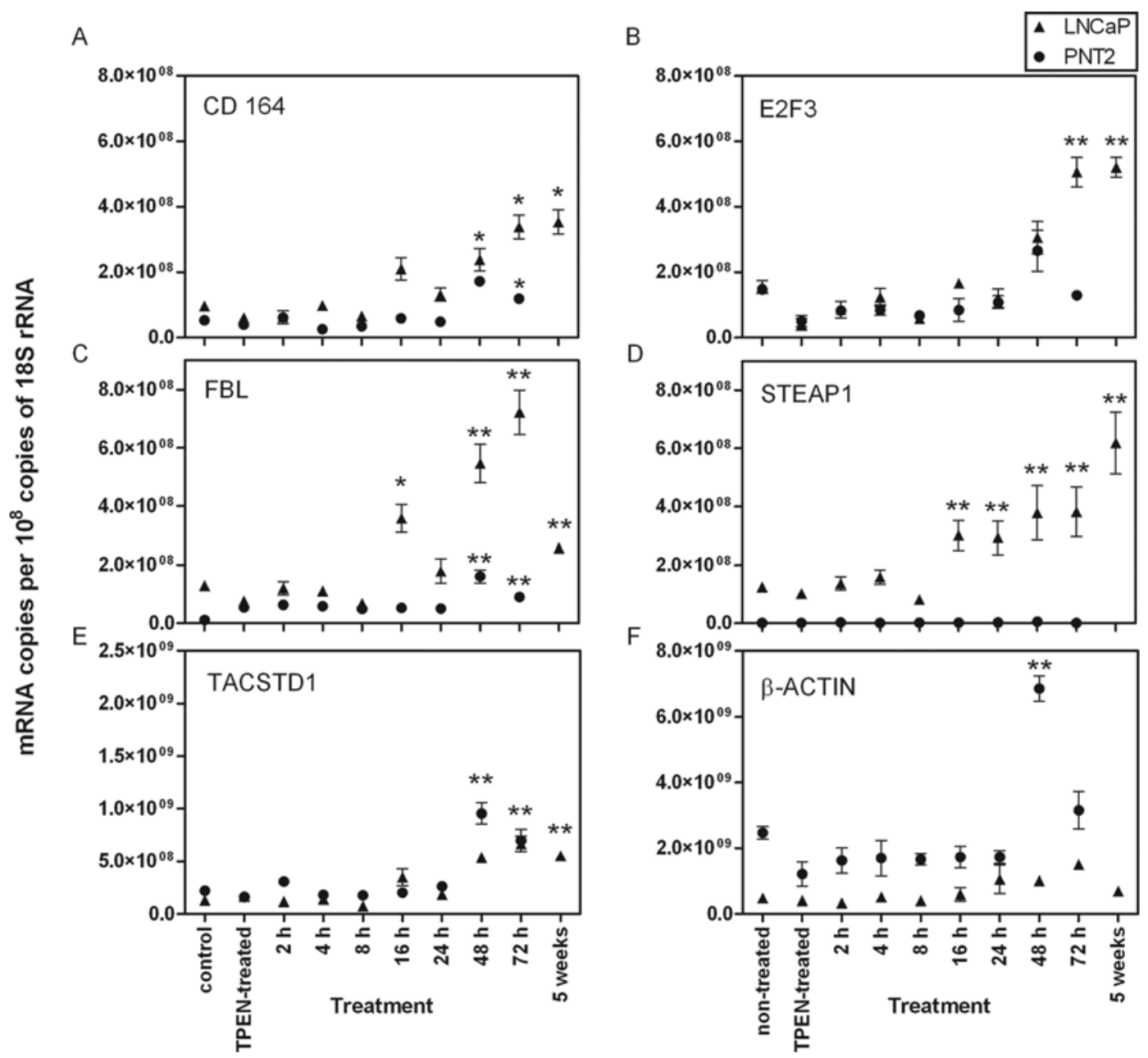

Figure 7. Expression profiles of LNCaP prostate cancer and PNT2 normal cells genes responding to the short- and long-term exposure to $\mathrm{Zn}^{2+}$. $\mathrm{LNCaP}$ and PNT2 cells were treated with $10 \mu \mathrm{g} / \mathrm{ml} \mathrm{Zn}^{2+}$ for 2, 4, 8, 16, 24, 48 and $72 \mathrm{~h}$. Control untreated cells and cells treated with $100 \mu \mathrm{M} N, N, N^{\prime}, N^{\prime}$-tetrakis (2-pyridylmethyl)ethylenediamine (TPEN) to chelate $\mathrm{Zn}^{2+}$ were incubated in parallel up to $72 \mathrm{~h}$. CD164, CD164 sialomucin (A); E2F3, E2F transcription factor 3 (B); FBL, fibrillarin (C); STEAP1, six-transmembrane epithelial antigen of the prostate 1 (D); TACSTD1, tumor-associated calcium signal transducer $1(\mathrm{E})$; and $B$-actin $(\mathrm{F}) .{ }^{*} \mathrm{p}<0.01,{ }^{* *} \mathrm{p}<0.001$ (t-test).

4.9 \pm 0.9 -fold, respectively, in comparison to the non $\mathrm{Zn}^{2+}$ treated LNCaP (Fig. 7).

The mRNA expression of CD164, FBL and TACSTD1 in the $\mathrm{Zn}^{2+}$-treated PNT2 increased only beginning at $48 \mathrm{~h}$ posttreatment and this was in contrast to $16 \mathrm{~h}$ in the $\mathrm{LNCaP}$ cells (Fig. 7). The mRNA levels of CD164, FBL and TACSTD1 increased by $3.3 \pm 0.1$-fold, $13.5 \pm 1.9$-fold and $4.4 \pm 0.5$-fold higher than the non $\mathrm{Zn}^{2+}$-treated PNT2 cells (Fig. 7A, C and E). At $72 \mathrm{~h}$ post-treatment, the mRNA levels of $C D 164$, $F B L$ and TACSTD1 increased by $2.2 \pm 0.2$-fold, 7.6 \pm 1.0 -fold and 3.2 \pm 0.5 -fold higher than the $\mathrm{Zn}^{2+}$-treated PNT2 cells (Fig. 7A, C and E). The mRNA levels of the housekeeping gene, $\beta$-actin, also increased by $2.8 \pm 0.2$-fold and $1.3 \pm 0.2$-fold at 48 and $72 \mathrm{~h}$ post-treatment, respectively, in the non $\mathrm{Zn}^{2+}$-treated PNT2 cells (Fig. 7F). The levels of $\beta-$ actin mRNA were otherwise unchanged at other time points in both the $\mathrm{Zn}^{2+}$-treated LNCaP and PNT2 cells. The slight increase in $\beta$-actin mRNA was not unexpected as 18S rRNA was used for normalization of the data in the study and it has its shortcomings $(60,61)$.

The RT-qPCR results from the study showed that the cell growth promoting genes CD164, FBL and TACSTD1 were responsive to the high intracellular $\mathrm{Zn}^{2+}$ treatment in both PNT2 prostate normal and LNCaP prostate cancer cells (Table IV). FBL and STEAP1, however, were constitutively higher in LNCaP cells in comparison to the PNT2 cells. FBL and STEAP1 were especially very high in LNCaP cells. The $E 2 F 3$ gene responded to the $\mathrm{Zn}^{2+}$ treatment in $\mathrm{LNCaP}$, but not PNT2 cells. STEAP1 expression was not responsive to the $\mathrm{Zn}^{2+}$ treatment in either cells and perhaps reflects the absence of pathways involving $\mathrm{Zn}^{2+}$ in the regulation of STEAP1 expression. Collectively these findings suggested that among the genes investigated only $C D 164, F B L$ and $T A C S T D 1$ were responsive to changes in the intracellular zinc concentration in prostate normal as well as cancer cells and despite the constitutively high level of expression in LNCaP cells, FBL gene can still be superinduced in the presence of supraphysiologic $\mathrm{Zn}^{2+}$.

\section{Discussion}

The normal prostate gland has a high level of $\mathrm{Zn}^{2+}$. Its role in prostate cell growth and gene expression, however, remains unclear. It is known that the $\mathrm{Zn}^{2+}$ level is significantly reduced 
in prostate malignancies. The present study investigates the effects of restoring high intracellular $\mathrm{Zn}^{2+}$ to $\mathrm{LNCaP}$ prostate cancer cells and its effects on cell growth and specific gene expression. An environment of high intracellular $\mathrm{Zn}^{2+}$ level is restored to the $\mathrm{LNCaP}$ prostate cancer cells by continuously culturing the cells over a 5-week period in growth media supplemented with physiologic $(1 \mu \mathrm{g} / \mathrm{ml})$ and supraphysiologic $(10 \mu \mathrm{g} / \mathrm{ml})$ concentrations of $\mathrm{Zn}^{2+}$. The treatment successfully increased the intracellular $\mathrm{Zn}^{2+}$ concentration and the number of zincosomes, a $\mathrm{Zn}^{2+}$-specific vesicle (23). Results from our microarray study, further suggest that the increase in intracellular $\mathrm{Zn}^{2+}$ level is also reflected by the increase in mRNA expressions of MT-1G and MT-1F which are radical scavengers that chelate and sequester excessive metal ions (11). The $\mathrm{Zn}^{2+}$ treatment, however, did not result in significant changes in the mRNA expression of $\mathrm{Zn}^{2+}$ transporters, hZIP-1 and ZnT1, which is in agreement with an earlier report (62) suggesting that regulation of these transporter gene expressions is not directly regulated by the intracellular $\mathrm{Zn}^{2+}$ level.

It is shown in the present study that cells treated with supraphysiologic $\mathrm{Zn}^{2+}$ exhibited reduced cell proliferation rate at the exponential point only. The inhibition is transient as the cell proliferation rate and anchorage-independent growth later attained the levels comparable to that of untreated cells. These results are incongruent with an earlier study that shows that there is no induction of senescence or apoptosis in the $\mathrm{Zn}^{2+}$-treated cell cultures (24). It also suggests that somehow the initial inhibitory effects of $\mathrm{Zn}^{2+}$ on $\mathrm{LNCaP}$ cell proliferation is reversed in the continuous presence of high intracellular $\mathrm{Zn}^{2+}$ hence, allowing the cancer cells to attain its normal cancerous cell growth rate.

Contradicting findings with regards to the effects of $\mathrm{Zn}^{2+}$ on prostate cancer cell growth and invasion have been reported $(18,22,63-65)$. While there are suggestions that dietary zinc supplementation protects against oxidative damage, reduces cancer risk (66) and is beneficial against prostate tumorigenesis (67), recent reports showed that advanced prostate cancer is associated with high intake of zinc (68-70). Higher intake of dietary zinc could also potentiate the development of BPH and progression towards cancer $(71,72)$. These reports raised concern of the potential detrimental outcomes of long-term use of high zinc-supplements in men even though the reason behind the increased in prostate cancer risk is unclear. To date, no satisfactory mechanisms have been forwarded to explain these seemingly contradicting roles of zinc in prostate cancer tumorigenesis. In an earlier study, it was shown that $\mathrm{Zn}^{2+}$ deficiency in normal prostate epithelial cells resulted in altered expression of genes associated with cell cycle, DNA damage/repair and gene transcription, suggesting that $\mathrm{Zn}^{2+}$ has a protective role in DNA damage and protection against cancer development (15). Results from the present study, however, showed that the LNCaP cells retained its cancerous proliferative rate and properties even though the expression of DNA damage/ repair, oxidative stress and apoptosis-related genes are upregulated in the presence of supraphysiologic zinc. This implies that there are potentially other zinc-associated mechanisms involved in the survival of the prostate cancer cells. Results presented here also showed that prostate cancer cell proliferation in the presence of supraphysiologic concentration of $\mathrm{Zn}^{2+}$ is accompanied by high expression of FASN, FAD, TACSTD1, FBL, ADRM1, E2F3, CD164 and STEAPI genes. Earlier studies have shown that $C D 164$ (44) and TACSTD1 (49) are overexpressed in prostate cancer tissues where $\mathrm{Zn}^{2+}$ level is known to be low. While the expressions of these genes are constitutively high in prostatic cancer cells, restoration of high intracellular $\mathrm{Zn}^{2+}$ did not reduce their expressions, on the contrary it superinduced the expressions of these genes suggesting that the regulation of these genes by $\mathrm{Zn}^{2+}$ is lost irreversibly in prostatic cancer cells. These genes are known to promote prostate cancer cell proliferation, aggressiveness and for some of these genes, the expression is associated with poor survival outcomes of cancer patients. We also found that CD164, FBL and TACSTD1 were regulated by $\mathrm{Zn}^{2+}$ in normal prostate PNT2 cells and these suggest that while $\mathrm{Zn}^{2+}$ initially suppresses cell growth, perhaps by repressing the expressions of selected growth promoting genes, it could also alternatively facilitate the survival of prostate cancer cell through mechanisms involving these very genes, possibly through an autostimulating pathways that superinduce the expression of the genes. Hence, prolonged high $\mathrm{Zn}^{2+}$-treatment could actually induce aggressive behavior of the prostate cancer cells. This suggestion offers a possible explanation to the development of prostate cancer. Perhaps during the very early stages of prostate cancer, the presence of relatively high level of zinc regulates the expression of these genes and only when significant subsequent changes in $\mathrm{Zn}^{2+}$ homeostasis occur that it trigger uncontrolled prostate cell growth leading to cancer.

How $\mathrm{Zn}^{2+}$ affects $C D 164, F B L$ and TACSTD1 is still unclear. CD164 and TACSTD1 (Ep-CAM) are cell adhesion molecules important for cell migration, proliferation, and differentiation $(73,74)$. CD164 is implicated in prostate cancer metastasis by promoting the immobilization of cancer cells to bone marrow through the CXCL12/CXCR4 pathway (44). Whereas, fibrillarin $(F B L)$, another gene found constitutively high in LNCaP cells and is superinduced by high intracellular $\mathrm{Zn}^{2+}$ is a nucleolar $\mathrm{U} 3$ ribonucleoprotein particle that is important for pre-rRNA processing during ribosomal biogenesis and maintains nuclear shape and cellular growth (75). FBL is also found upregulated in human cervical squamous cell carcinoma (56) and hepatocellular carcinoma (76). STEAP1, on the other hand is highly expressed in multiple cancer cells including prostate, bladder, colon, ovarian and Ewing sarcoma (77) and we showed here that its expression in LNCaP cells is $~ 56$-fold higher than in PNT2 prostate normal cells, yet it is not responsive to $\mathrm{Zn}^{2+}$ in comparison to other genes studied. STEAP1 is a transmembrane protein with a potential role in the reduction of copper and iron (78). It is likely therefore, that $\mathrm{Zn}^{2+}$ which does not participate in redox reaction (79) may not have an effect on STEAP1 expression. The mechanisms of how other genes except STEAP1 are superinduced following longterm high intracellular $\mathrm{Zn}^{2+}$ treatment are still unknown. We had previously shown that under similar conditions the $\mathrm{Zn}^{2+}$ regulation of $\mathrm{LNCaP}$ cell growth could be mediated through the ERK/VHR/ZAP-70 pathway (23). The finding in the present study that genes such as ClQBPl (31), SHCl (80), 
AHR (81), ARF4 (82), RPS6KB2 (83) and KTN1 (84) are upregulated following $\mathrm{Zn}^{2+}$ treatment supported this suggestion, as these genes are known to be regulated through the ERK signaling pathway highlighting the potential importance of this pathway in prostate cancer biogenesis.

Taken together, findings from the present study offer possible explanations to the contradicting reports on the influence of zinc on prostate cancer development. $\mathrm{Zn}^{2+}$ may have suppressive effects on prostate cancer cell growth initially but its presence at high level under transformed condition may results in deleterious consequences. $\mathrm{Zn}^{2+}$ based therapy for prostate cancer, hence, may potentially contribute to undesirable outcomes.

\section{Acknowledgements}

This study was funded in parts by Program Intensification of Research In Priority Area (IRPA) Grant No. 06-02-031025 (Oracle 8361025), University of Malaya short-term research grants VotF-382/2005C and VotF-0173/2003B. P.F. Wong is the recipient of the National Science Fellowship (NSF) Ph.D. Scholarship from the Ministry of Science, Technology and Innovations, Malaysia.

\section{References}

1. Vasto S, Candore G, Listi F, Balistreri CR, Colonna-Romano G, Malavolta M, Lio D, Nuzzo D, Mocchegiani E, Di Bona D and Caruso C: Inflammation, genes and zinc in Alzheimer's disease. Brain Res Rev 58: 96-105, 2008.

2. Devirgiliis C, Zalewski PD, Perozzi G and Murgia C: Zinc fluxes and zinc transporter genes in chronic diseases. Mutat Res 622: 84-93, 2007.

3. Donadelli M, Dalla Pozza E, Costanzo C, Scupoli MT, Scarpa A and Palmieri M: Zinc depletion efficiently inhibits pancreatic cancer cell growth by increasing the ratio of antiproliferative/ proliferative genes. J Cell Biochem 104: 202-212, 2008.

4. Costello LC, Feng P, Milon B, Tan M and Franklin RB: Role of zinc in the pathogenesis and treatment of prostate cancer: critical issues to resolve. Prostate Cancer Prostatic Dis 7: 111-117, 2004

5. Kumar A, Chatopadhyay T, Raziuddin M and Ralhan R: Discovery of deregulation of zinc homeostasis and its associated genes in esophageal squamous cell carcinoma using cDNA microarray. Int J Cancer 120: 230-242, 2007.

6. Blanchard RK, Moore JB, Green CL and Cousins RJ: Modulation of intestinal gene expression by dietary zinc status: effectiveness of cDNA arrays for expression profiling of a single nutrient deficiency. Proc Natl Acad Sci USA 98: 13507-13513, 2001.

7. Sun JY, Wang JF, Zi NT, Jing MY and Weng XY: Gene expression profiles analysis of the growing rat liver in response to different zinc status by cDNA microarray analysis. Biol Trace Elem Res 115: 169-185, 2007.

8. Tom Dieck H, Doring F, Roth HP and Daniel H: Changes in rat hepatic gene expression in response to zinc deficiency as assessed by DNA arrays. J Nutr 133: 1004-1010, 2003

9. Haase H, Mazzatti DJ, White A, Ibs KH, Engelhardt G, Hebel S, Powell JR and Rink L: Differential gene expression after zinc supplementation and deprivation in human leukocyte subsets. Mol Med 13: 362-370, 2007.

10. Aydemir TB, Blanchard RK and Cousins RJ: Zinc supplementation of young men alters metallothionein, zinc transporter, and cytokine gene expression in leukocyte populations. Proc Natl Acad Sci USA 103: 1699-1704, 2006.

11. Cousins RJ, Blanchard RK, Popp MP, Liu L, Cao J, Moore JB and Green CL: A global view of the selectivity of zinc deprivation and excess on genes expressed in human THP-1 mononuclear cells. Proc Natl Acad Sci USA 100: 6952-6957, 2003
12. Andree KB, Kim J, Kirschke CP, Gregg JP, Paik H, Joung H, Woodhouse L, King JC and Huang L: Investigation of lymphocyte gene expression for use as biomarkers for zinc status in humans. J Nutr 134: 1716-1723, 2004.

13. Beck FW, Li Y, Bao B, Prasad AS and Sarkar FH: Evidence for reprogramming global gene expression during zinc deficiency in the HUT-78 cell line. Nutrition 22: 1045-1056, 2006.

14. Kindermann B, Doring F, Pfaffl M and Daniel H: Identification of genes responsive to intracellular zinc depletion in the human colon adenocarcinoma cell line HT-29. J Nutr 134: 57-62, 2004.

15. Yan M, Song Y, Wong CP, Hardin K and Ho E: Zinc deficiency alters DNA damage response genes in normal human prostate epithelial cells. J Nutr 138: 667-673, 2008.

16. Ebisch IM, Thomas CM, Peters WH, Braat DD and SteegersTheunissen RP: The importance of folate, zinc and antioxidants in the pathogenesis and prevention of subfertility. Hum Reprod Update 13: 163-174, 2007.

17. Zaichick V, Sviridova TV and Zaichick SV: Zinc in the human prostate gland: normal, hyperplastic and cancerous. Int Urol Nephrol 29: 565-574, 1997.

18. Uzzo RG, Crispen PL, Golovine K, Makhov P, Horwitz EM and Kolenko VM: Diverse effects of zinc on NF-kappaB and AP-1 transcription factors: implications for prostate cancer progression. Carcinogenesis 27: 1980-1990, 2006.

19. Gioeli D: Signal transduction in prostate cancer progression. Clin Sci (London) 108: 293-308, 2005.

20. Feng P, Li TL, Guan ZX, Franklin RB and Costello LC: Direct effect of zinc on mitochondrial apoptogenesis in prostate cells. Prostate 52: 311-318, 2002.

21. Ishii K, Usui S, Sugimura Y, Yamamoto H, Yoshikawa K and Hirano K: Inhibition of aminopeptidase N (AP-N) and urokinase-type plasminogen activator (uPA) by zinc suppresses the invasion activity in human urological cancer cells. Biol Pharm Bull 24: 226-230, 2001.

22. Boissier S, Ferreras M, Peyruchaud O, Magnetto S, Ebetino FH, Colombel M, Delmas P, Delaisse JM and Clezardin P: Bisphosphonates inhibit breast and prostate carcinoma cell invasion, an early event in the formation of bone metastases. Cancer Res 60: 2949-2954, 2000.

23. Wong PF and Abubakar S: High intracellular $\mathrm{Zn}^{2+}$ ions modulate the VHR, ZAP-70 and ERK activities of LNCaP prostate cancer cells. Cell Mol Biol Lett 13: 375-390, 2008.

24. Wong PF and Abubakar S: LNCaP prostate cancer cells are insensitive to zinc-induced senescence. J Trace Elem Med Biol 22: 242-247, 2008

25. Benjamini Y and Hochberg Y: Controlling the false discovery rate: a practical and powerful approach to multiple testing. J R Stat Soc Series B (Methodological) 57: 289-300, 1995.

26. Beisvag V, Junge FK, Bergum H, Jolsum L, Lydersen S, Gunther CC, Ramampiaro H, Langaas M, Sandvik AK and Laegreid A: GeneTools- application for functional annotation and statistical hypothesis testing. BMC Bioinformatics 7: $470,2006$.

27. Huggett J, Dheda K, Bustin S and Zumla A: Real-time RTPCR normalisation, strategies and considerations. Genes Immun 6: 279-284, 2005

28. Rouault JP, Falette N, Guehenneux F, Guillot C, Rimokh R, Wang Q, Berthet C, Moyret-Lalle C, Savatier P, Pain B, Shaw P, Berger R, Samarut J, Magaud JP, Ozturk M, Samarut C and Puisieux A: Identification of BTG2, an antiproliferative p53-dependent component of the DNA damage cellular response pathway. Nat Genet 14: 482-486, 1996.

29. Ohtsuka T, Ryu H, Minamishima YA, Ryo A and Lee SW: Modulation of p53 and p73 levels by cyclin G: implication of a negative feedback regulation. Oncogene 22: 1678-1687, 2003.

30. Machida T, Fujita T, Ooo ML, Ohira M, Isogai E, Mihara M, Hirato J, Tomotsune D, Hirata T, Fujimori M, Adachi W and Nakagawara A: Increased expression of proapoptotic BMCC1, a novel gene with the BNIP2 and Cdc42GAP homology $(\mathrm{BCH})$ domain, is associated with favorable prognosis in human neuroblastomas. Oncogene 25: 1931-1942, 2006.

31. Meenakshi J, Anupama, Goswami SK and Datta K: Constitutive expression of hyaluronan binding protein 1 (HABP1/p32/gC1qR) in normal fibroblast cells perturbs its growth characteristics and induces apoptosis. Biochem Biophys Res Commun 300: 686-693, 2003 
32. Lee YH, Lee JC, Moon HJ, Jung JE, Sharma M, Park BH, Yi HK and Jhee EC: Differential effect of oxidative stress on the apoptosis of early and late passage human diploid fibroblasts: implication of heat shock protein 60 . Cell Biochem Funct 26: 502-508, 2008

33. Budanov AV, Shoshani T, Faerman A, Zelin E, Kamer I, Kalinski H, Gorodin S, Fishman A, Chajut A, Einat P, Skaliter R, Gudkov AV, Chumakov PM and Feinstein E: Identification of a novel stress-responsive gene Hi95 involved in regulation of cell viability. Oncogene 21: 6017-6031, 2002.

34. Ramsden JJ: MARCKS: a case of molecular exaptation? Int J Biochem Cell Biol 32: 475-479, 2000.

35. Martinez-Arribas F, Agudo D, Pollan M, Gomez-Esquer F, Diaz-Gil G, Lucas R and Schneider J: Positive correlation between the expression of X-chromosome RBM genes (RBMX, RBM3, RBM10) and the proapoptotic Bax gene in human breast cancer. J Cell Biochem 97: 1275-1282, 2006.

36. Jin R, Huang J, Tan PH and Bay BH: Clinicopathological significance of metallothioneins in breast cancer. Pathol Oncol Res 10: 74-79, 2004

37. Tiberi L, Faisal A, Rossi M, Di Tella L, Franceschi C and Salvioli S: p66(Shc) gene has a pro-apoptotic role in human cell lines and it is activated by a p53-independent pathway. Biochem Biophys Res Commun 342: 503-508, 2006

38. Iwanaga R, Komori $\mathrm{H}$ and Ohtani K: Differential regulation of expression of the mammalian DNA repair genes by growth stimulation. Oncogene 23: 8581-8590, 2004

39. Kanu $\mathrm{N}$ and Behrens A: ATMINistrating ATM signalling: regulation of ATM by ATMIN. Cell Cycle 7: 3483-3486, 2008 .

40. Bladen CL, Udayakumar D, Takeda Y and Dynan WS: Identification of the polypyrimidine tract binding proteinassociated splicing factor.p54(nrb) complex as a candidate DNA double-strand break rejoining factor. J Biol Chem 280: 5205-5210, 2005

41. Singh R, Lemire J, Mailloux RJ and Appanna VD: A novel strategy involved anti-oxidative defense: the conversion of NADH into NADPH by a metabolic network. PLoS One 3: e2682, 2008

42. Lu DD, Chen YC, Zhang XR, Cao XR, Jiang HY and Yao L: The relationship between metallothionein-1F (MT1F) gene and hepatocellular carcinoma. Yale J Biol Med 76: 55-62, 2003.

43. Hellborg F, Qian W, Mendez-Vidal C, Asker C, KostAlimova M, Wilhelm M, Imreh S and Wiman KG: Human wig-1, a p53 target gene that encodes a growth inhibitory zinc finger protein. Oncogene 20: 5466-5474, 2001.

44. Havens AM, Jung Y, Sun YX, Wang J, Shah RB, Buhring HJ, Pienta KJ and Taichman RS: The role of sialomucin CD164 (MGC-24v or endolyn) in prostate cancer metastasis. BMC Cancer 6: 195, 2006.

45. Rossi S, Graner E, Febbo P, Weinstein L, Bhattacharya N, Onody T, Bubley G, Balk S and Loda M: Fatty acid synthase expression defines distinct molecular signatures in prostate cancer. Mol Cancer Res 1: 707-715, 2003.

46. Moore S, Knudsen B, True LD, Hawley S, Etzioni R, Wade C, Gifford D, Coleman I and Nelson PS: Loss of stearoyl-CoA desaturase expression is a frequent event in prostate carcinoma. Int J Cancer 114: 563-571, 2005

47. Ishiguro H, Uemura H, Fujinami K, Ikeda N, Ohta S and Kubota Y: $55 \mathrm{kDa}$ nuclear matrix protein $(\mathrm{nmt55}) \mathrm{mRNA}$ is expressed in human prostate cancer tissue and is associated with the androgen receptor. Int J Cancer 105: 26-32, 2003.

48. Bogni A, Cheng C, Liu W, Yang W, Pfeffer J, Mukatira S, French D, Downing JR, Pui CH and Relling MV: Genome-wide approach to identify risk factors for therapy-related myeloid leukemia. Leukemia 20: 239-246, 2006.

49. Went P, Vasei M, Bubendorf L, Terracciano L, Tornillo L, Riede U, Kononen J, Simon R, Sauter G and Baeuerle PA: Frequent high-level expression of the immunotherapeutic target Ep-CAM in colon, stomach, prostate and lung cancers. Br J Cancer 94: 128-135, 2006

50. Lapointe J, Li C, Higgins JP, van de Rijn M, Bair E, Montgomery K, Ferrari M, Egevad L, Rayford W, Bergerheim U, Ekman P, DeMarzo AM, Tibshirani R, Botstein D, Brown PO, Brooks JD and Pollack JR: Gene expression profiling identifies clinically relevant subtypes of prostate cancer. Proc Natl Acad Sci USA 101: 811-816, 2004
51. Rasheed S, Harris AL, Tekkis PP, Turley H, Silver A, McDonald PJ, Talbot IC, Glynne-Jones R, Northover JM and Guenther T: Hypoxia-inducible factor-1alpha and -2alpha are expressed in most rectal cancers but only hypoxia-inducible factor-1alpha is associated with prognosis. Br J Cancer 100: 1666-1673, 2009.

52. Mollaoglu N, Vairaktaris E, Nkenke E, Neukam FW and Ries J: Expression of MAGE-A12 in oral squamous cell carcinoma. Dis Markers 24: 27-32, 2008.

53. Vaarala MH, Porvari KS, Kyllonen AP, Mustonen MV, Lukkarinen $\mathrm{O}$ and Vihko PT: Several genes encoding ribosomal proteins are over-expressed in prostate-cancer cell lines: confirmation of L7a and L37 over-expression in prostate-cancer tissue samples. Int J Cancer 78: 27-32, 1998.

54. Bai L and Merchant JL: A role for CITED2, a CBP/p300 interacting protein, in colon cancer cell invasion. FEBS Lett 581: 5904-5910, 2007

55. He H, Dai F, Yu L, She X, Zhao Y, Jiang J, Chen X and Zhao S: Identification and characterization of nine novel human small GTPases showing variable expressions in liver cancer tissues. Gene Expr 10: 231-242, 2002.

56. Choi YW, Kim YW, Bae SM, Kwak SY, Chun HJ, Tong SY, Lee HN, Shin JC, Kim KT, Kim YJ and Ahn WS: Identification of differentially expressed genes using annealing control primerbased GeneFishing in human squamous cell cervical carcinoma. Clin Oncol (R Coll Radiol) 19: 308-318, 2007.

57. Suzuki S, Takahashi S, Takeshita K, Hikosaka A, Wakita T, Nishiyama N, Fujita T, Okamura T and Shirai T: Expression of prothymosin alpha is correlated with development and progression in human prostate cancers. Prostate 66: 463-469, 2006.

58. Rizzi F, Belloni L, Crafa P, Lazzaretti M, Remondini D, Ferretti S, Cortellini P, Corti A and Bettuzzi S: A novel gene signature for molecular diagnosis of human prostate cancer by RT-qPCR. PLoS One 3: e3617, 2008.

59. Dunn TA, Chen S, Faith DA, Hicks JL, Platz EA, Chen Y, Ewing CM, Sauvageot J, Isaacs WB, De Marzo AM and Luo J: A novel role of myosin VI in human prostate cancer. Am J Pathol 169: 1843-1854, 2006.

60. Aerts JL, Gonzales MI and Topalian SL: Selection of appropriate control genes to assess expression of tumor antigens using real-time RT-PCR. Biotechniques 36: 84-91, 2004

61. Vandesompele J, De Preter K, Pattyn F, Poppe B, Van Roy N, De Paepe A and Speleman F: Accurate normalization of real-time quantitative RT-PCR data by geometric averaging of multiple internal control genes. Genome Biol 3: Research0034, 2002.

62. Albrecht AL, Somji S, Sens MA, Sens DA and Garrett SH: Zinc transporter mRNA expression in the RWPE-1 human prostate epithelial cell line. Biometals 21: 405-416, 2008.

63. Feng P, Liang JY, Li TL, Guan ZX, Zou J, Franklin R and Costello LC: Zinc induces mitochondria apoptogenesis in prostate cells. Mol Urol 4: 31-36, 2000.

64. Ishii K, Otsuka T, Iguchi K, Usui S, Yamamoto H, Sugimura Y, Yoshikawa K, Hayward SW and Hirano K: Evidence that the prostate-specific antigen (PSA)/ $\mathrm{Zn}^{2+}$ axis may play a role in human prostate cancer cell invasion. Cancer Lett 207: 79-87, 2004.

65. Nemoto K, Kondo Y, Himeno S, Suzuki Y, Hara S, Akimoto M and Imura N: Modulation of telomerase activity by zinc in human prostatic and renal cancer cells. Biochem Pharmacol 59: 401-405, 2000

66. Ho E: Zinc deficiency, DNA damage and cancer risk. J Nutr Biochem 15: 572-578, 2004

67. Franklin RB and Costello LC: Zinc as an anti-tumor agent in prostate cancer and in other cancers. Arch Biochem Biophys 463: 211-217, 2007.

68. Gallus S, Foschi R, Negri E, Talamini R, Franceschi S, Montella M, Ramazzotti V, Tavani A, Dal Maso L and La Vecchia C: Dietary zinc and prostate cancer risk: a casecontrol study from Italy. Eur Urol 52: 1052-1056, 2007.

69. Lawson KA, Wright ME, Subar A, Mouw T, Hollenbeck A, Schatzkin A and Leitzmann MF: Multivitamin use and risk of prostate cancer in the National Institutes of Health-AARP Diet and Health Study. J Natl Cancer Inst 99: 754-764, 2007.

70. Leitzmann MF, Stampfer MJ, Wu K, Colditz GA, Willett WC and Giovannucci EL: Zinc supplement use and risk of prostate cancer. J Natl Cancer Inst 95: 1004-1007, 2003.

71. Lagiou P, Wuu J, Trichopoulou A, Hsieh CC, Adami HO and Trichopoulos D: Diet and benign prostatic hyperplasia: a study in Greece. Urology 54: 284-290, 1999. 
72. Moyad MA: Zinc for prostate disease and other conditions: a little evidence, a lot of hype, and a significant potential problem. Urol Nurs 24: 49-52, 2004.

73. Zannettino AC, Buhring HJ, Niutta S, Watt SM, Benton MA and Simmons PJ: The sialomucin CD164 (MGC-24v) is an adhesive glycoprotein expressed by human hematopoietic progenitors and bone marrow stromal cells that serves as a potent negative regulator of hematopoiesis. Blood 92: 2613-2628, 1998.

74. Trzpis M, McLaughlin PM, de Leij LM and Harmsen MC: Epithelial cell adhesion molecule: more than a carcinoma marker and adhesion molecule. Am J Pathol 171: 386-395, 2007.

75. Amin MA, Matsunaga S, Ma N, Takata H, Yokoyama M Uchiyama $\mathrm{S}$ and Fukui K: Fibrillarin, a nucleolar protein, is required for normal nuclear morphology and cellular growth in HeLa cells. Biochem Biophys Res Commun 360: 320-326, 2007.

76. Zhang JY, Wang X, Peng XX and Chan EK: Autoantibody responses in Chinese hepatocellular carcinoma. J Clin Immuno 22: 98-105, 2002.

77. Hubert RS, Vivanco I, Chen E, Rastegar S, Leong K, Mitchell SC, Madraswala R, Zhou Y, Kuo J, Raitano AB, Jakobovits A, Saffran DC and Afar DE: STEAP: a prostate-specific cellsurface antigen highly expressed in human prostate tumors. Proc Natl Acad Sci USA 96: 14523-14528, 1999.

78. Ohgami RS, Campagna DR, McDonald A and Fleming MD: The Steap proteins are metalloreductases. Blood 108: 1388-1394, 2006
79. Berg JM and Shi Y: The galvanization of biology: a growing appreciation for the roles of zinc. Science 271: 1081-1085, 1996.

80. Arany I, Faisal A, Nagamine Y and Safirstein RL: p66shc inhibits pro-survival epidermal growth factor receptor/ERK signaling during severe oxidative stress in mouse renal proximal tubule cells. J Biol Chem 283: 6110-6117, 2008.

81. Hanlon PR, Ganem LG, Cho YC, Yamamoto M and Jefcoate CR: AhR- and ERK-dependent pathways function synergistically to mediate 2,3,7,8-tetrachlorodibenzo-p-dioxin suppression of peroxisome proliferator-activated receptor-gammal expression and subsequent adipocyte differentiation. Toxicol Appl Pharmacol 189: 11-27, 2003

82. Kim SW, Hayashi M, Lo JF, Yang Y, Yoo JS and Lee JD: ADP-ribosylation factor 4 small GTPase mediates epidermal growth factor receptor-dependent phospholipase D2 activation. J Biol Chem 278: 2661-2668, 2003.

83. Casas-Terradellas E, Tato I, Bartrons R, Ventura F and Rosa JL: ERK and p38 pathways regulate amino acid signalling. Biochim Biophys Acta 1783: 2241-2254, 2008.

84. Hotta K, Tanaka K, Mino A, Kohno H and Takai Y: Interaction of the Rho family small $\mathrm{G}$ proteins with kinectin, an anchoring protein of kinesin motor. Biochem Biophys Res Commun 225: 69-74, 1996. 